\title{
EL TRATADO CONSTITUCIONAL \\ A LA LUZ DE LOS PRINCIPIOS \\ DEL MODERNO CONSTITUCIONALISMO
}

\author{
ÁNGELA FIGUERUELO BURRIEZA
}




\section{SUMARIO}

1. El FRACASO DE LA CUMBRE DE BRUSELAS EN DICIEMBRE DE 2003 Y EL CONSENSO OBTENIDO EN JUNIO DE 2004. 2. LA NECESARIA REFORMA DEL TRATADO DE NIZA DE 2001. 3. El TRATAdo CONSTITUCIONAL A LA LUZ DE LOS PRINCIPIOS DEL MODERNO CONSTITUCIONALISMO. 4. EL NOVEDOSO PROCEDIMIENTO DE REFORMA DEL TRATADO de Niza. 5. La Ausencia de Poder Constituyente europeo: Los Estados SEÑORES DE LOS TRATADOS. 6. EL PRINCIPIO LIBERAL COMO SISTEMA DE GARANTÍAS DE la deMOCRACIA. 7. El TRATAdo CONSTITUCIONAL Y EL PRINCIPIO DE SUPREMACÍA CONSTITUCIONAL. 8. LA INTEGRACIÓN EUROPEA COMO PROCESO ABIERTO. 9. EL DESBLOQUEO DE LAS NEGOCIACIONES. 10. El CONSENSO SOBRE EL TRATADO ConSTITUCIONAL. LA CUMBRE DE BRUSELAS DE LOS DÍAS 17 Y 18 DE JUNIO DE 2004. 11. EL REFERÉNDUM ESPAÑOL SOBRE EL TRATADO CONSTITUCIONAL (OUE NO CONTRADICE LOS POSTULADOS CONSTITUCIONALES). 


\title{
EL TRATADO CONSTITUCIONAL A LA LUZ DE LOS PRINCIPIOS DEL MODERNO CONSTITUCIONALISMO
}

\author{
POR \\ ÁNGELA FIGUERUELO BURRIEZA \\ Pfra. Titular de Derecho Constitucional \\ Universidad de Salamanca \\ "Europa no será una realidad hasta que no sea \\ una la conciencia de los europeos"
}

(S. DE MAdARIAgA.)

\begin{abstract}
RESUMEN
El objeto de análisis en este trabajo es el Tratado por el que se establece una Constitución para Europa, elaborado por la Convención Europea y presentado al Consejo Europeo de Salónica el 20 de junio de 2003. Su debate comenzó en la C.I.G. abierta en Roma el 4 de Octubre; el fracaso de la Cumbre de Bruselas de 13 de diciembre del mismo año provocó que el consenso de todos los Estados miembros, veinticinco, para su aprobación, no se alcanzase hasta la cumbre de Bruselas de 18 de junio de 2004, una vez que en el mes de marzo quedasen desbloqueadas las negociaciones. Finalmente este proyecto normativo fue firmado solemnemente en Roma el 29 de octubre de 2004 (Tratado de Roma II) quedando a la espera de su ratificación por todos los Estados
\end{abstract}


miembros conforme a lo dispuesto en sus respectivas constituciones. La fecha prevista para su entrada en vigencia es a finales de 2006. El estudio lo hemos efectuado bajo los parámetros de la teoría democrática del poder constituyente y a la luz de los principios del moderno constitucionalismo que impiden usar el nombre de Constitución en vano, y nos permiten sostener que la nueva norma de la Unión Europea sigue siendo un Tratado Internacional que reforma el Tratado de Niza de 2001.

\section{EL FRACASO DE LA CUMBRE DE BRUSELAS EN DICIEMBRE DE 2003 Y EL CONSENSO OBTENIDO EN JUNIO DE 2004}

El fracaso de la Cumbre de Bruselas celebrada los días 13 y 14 de diciembre del pasado año, hizo que la Conferencia Intergubernamental abierta en Roma el día 4 de octubre no consiguiera su principal objetivo: La aprobación del Tratado Constitucional. La prueba escrita del final dramático de la reunión del día 13 quedó plasmada en la declaración final que zanjó dicha C.I.G. La brevedad del texto se corresponde con el fracaso sin precedentes de la citada Cumbre en la cual los Jefes de Estado y de Gobierno de los veinticinco Estados miembros no lograron ponerse de acuerdo sobre el reparto de poder en la futura U.E. Dice así la Declaración final:

«El Consejo de Europa toma nota de que no ha sido posible para la Conferencia Intergubernamental lograr un acuerdo global sobre el Tratado Constitucional en este momento. Se le pide a la presidencia irlandesa que, sobre la base de consultas, haga una valoración de las perspectivas de progreso e informe al Consejo Europeo en marzo".

Así las cosas, Europa que es camino y no posada (ORTEGA y GASSET), continúa su andadura en los últimos tiempos con algunas dificultades; los Estados, señores de los Tratados, siguen ejerciendo sobre ellos su dominio y esto ha hecho que los objetivos del nuevo Tratado para que la Unión Europea del siglo XXI afronte los retos que se le han planteado, no pudieran conseguirse hasta la cumbre de junio de 2004 . Las causas del fracaso, debido a las múltiples desconfianzas acumuladas durante años, son más preocupantes que los efectos puesto que, el Tratado de Niza de 2001, en vigor desde febrero de 2002, va a regir el sistema institucional hasta el 2009 y el 2004. Luego, desde el punto de vista práctico poco importaba que el nuevo Tratado se aprobara en el 2003 ó en el 2004. La crisis actual es consecuencia de que la desconfianza mutua acumulada durante años ha colmado el vaso y se ha manifestado en esta necesaria, pero no bien preparada, ampliación y, la 
existencia de una superpotencia solitaria ha hecho que algunos países fundadores de la U.E. hayan pretendido dirigir la elaboración del Tratado Constitucional (ALDECOA).

España y Polonia fueron los Estados miembros señalados como causantes del fracaso de la Cumbre de Bruselas por ejercer una defensa numantina del reparto de votos en el Consejo tal y como había sido establecido en el Tratado de Niza. Según este Tratado el reparto de poder beneficia a España y Polonia que disponían de 27 votos en el Consejo, sólo dos menos que los grandes países y con facilidad de formar minorías de bloqueo de 90 votos con algunos aliados. En contraprestación, España perdió un Comisario y redujo de 64 a 50 el número de escaños en la Eurocámara. El problema se planteó en la primavera de 2003, cuando Giscard, presidente de la Convención, puso sobre el tapete sin discusión previa en el órgano que presidía, la fórmula clave para el nuevo reparto de poder: las decisiones por mayoría cualificada en el Consejo de la Unión Europea serían válidas cuando fueran apoyadas por más de la mitad de los países que representasen al menos a tres quintas partes, el $60 \%$ de la población europea. Es la denominada doble mayoría, 50\% / 60\% que quiere representar a quienes legitiman la Unión Europea: los Estados y los ciudadanos, y que indudablemente beneficia a Alemania que con sus 82 millones de habitantes duplica el poder en número de votos respecto a lo que obtuvo en Niza. A esta fórmula es a la que se opusieron España y Polonia. Este importante fleco, unido a la discrepancia en el número de Comisarios en la Comisión y al reparto de escaños en la Eurocámara dieron al traste, desafortunadamente, con la Cumbre de Bruselas cuando el eje franco-alemán levantó la sesión del 13 de diciembre de 2003 en Bruselas (J. Martín y Pérez de NAClares).

Este fracaso fue lamentado, entre otros, por el Parlamento Europeo que en una resolución aprobada en Estrasburgo, alertó del riesgo de que dicho fracaso, en parte abonado también por el incumplimiento del Pacto de Estabilidad por Francia y Alemania con sus elevados déficit, abriera la puerta a una "Europa a dos velocidades" e incluso "a la fragmentación de la Unión". A partir de aquí las cosas deben ir más despacio para evitar que esta frustración se repita y además por los amplios acontecimientos producidos a lo largo del 2004: el 1 de mayo surgieron diez nuevos Estados miembros de pleno derecho, el 13 de junio los ciudadanos europeos acudimos a las urnas para renovar la Eurocámara sin haber podido poder manifestarnos sobre el nuevo Tratado y en otoño se renovó la Comisión... Por todo ello, la norma en cuestión, elaborada durante dieciséis meses (marzo de 2002-julio de 2003) fue objeto de discusión a partir de marzo de 2004, una vez que se 
desbloquearon las negociaciones bajo la presidencia irlandesa, obteniendo el consenso necesario en la cumbre de Bruselas de 17 y 18 de junio de 2004, (tras el atentado terrorista de Madrid del 11-M y el triunfo de los socialistas en España en las elecciones del 14-M). El reparto del poder se adoptará conforme a la fórmula $55 \% / 65 \%$ propuesto por la presidencia de turno. Esta fórmula satisface a España porque, además de representar a los Estados y a los ciudadanos, de cuya voluntad nace esta norma jurídica, no nos aleja de los resultados conseguidos en Niza; a ello contribuyen una serie de cautelas o sistemas de doble llave que hacen de la fórmula un método farragoso y complicado, pero que ha logrado el consenso de los países pequeños y medianos.

\section{LA NECESARIA REFORMA DEL TRATADO DE NIZA DE 2001}

La Constitución Española de 1978 nació con clara vocación europeísta. Buena prueba de ello es la autorruptura constitucional contemplada en el art. 93 que permite ceder, mediante ley orgánica, a instancias supranacionales el ejercicio de competencias derivadas de la propia Constitución. Los debates en sede constituyente ponen de manifiesto que dicho precepto fue introducido para poder entrar a formar parte de las Comunidades Europeas sin necesidad de reformar previamente la Constitución. En otros países del entorno europeo, fue necesario proceder a ello.

Con fundamento en el precitado artículo firmó España, junto con Portugal, el Tratado de Adhesión en el verano de 1985 y el día 1 de enero de 1986 comenzamos a ser miembros de pleno derecho de esa organización supranacional. Desde entonces se ha recorrido un largo camino: Hemos acompañado a la "Europa Unida» en el Acta Única Europea, en el Tratado de Maastricht (que provocó la única reforma sufrida por la norma suprema española en el art. 13.2), en el Tratado de Ámsterdam, en el Tratado de Niza y ahora estamos acompañándola en la aventura del "Tratado por el que se establece una Constitución para Europa».

Este último Tratado obedece a la dinámica del proceso abierto, hacia dentro y hacia fuera, que se marcó para la integración Europa. Se trata, pues, de un paso más en dicha integración que abre la puerta a la ampliación más numerosa sufrida por la Unión Europea a lo largo de su historia (en 2004 diez nuevos países y otros tres o cuatro en un breve período de tiempo). Esta ampliación requiere de modificaciones urgentes y necesarias para permitir el funcionamiento de unas instituciones que nacen con una organización supranacional de seis miem- 
bros y deben ser adaptadas para una Comunidad que se aproxima a los treinta. Requisito imprescindible para su consolidación es conseguir un mayor desarrollo e intensificación del proceso de construcción Europea en cuanto organización internacional de carácter supranacional (URREA, Martín, MANGAS).

Los fracasos parciales de las Conferencias de Ámsterdam y Niza nos condujeron a un nuevo período de incertidumbre política. Por ello, la Declaración n. ${ }^{\circ} 23$, anexa al Tratado de Niza, anunciaba una nueva Conferencia Intergubernamental para el 2004, que al final se adelantó al otoño de 2003. El Consejo Europeo de Laeken, de diciembre de 2001, siguiendo el ejemplo exitoso del Consejo Europeo de Colonia decidió nombrar una CONVENCIÓN, con representación de los Parlamentos Nacionales, del Parlamento Europeo, de los Presidentes de los Gobiernos y de la Comisión. También estaban representados los países candidatos a la ampliación y la sociedad civil pudo expresar sus opiniones y hacerlas llegar a la Convención; A este órgano plural, formado por más de un centenar de miembros y en concreto al PRAESIDIUM, (compuesto por 12 miembros) verdadero núcleo de la Convención y redactor del primer borrador, se le encomendó la primera fase del nuevo Tratado por el cual se debía modificar el recientemente aprobado Tratado de Niza. Tenía la función de redactar un documento normativo, sobre cuyo nombre se ha discutido mucho y que ha sido el punto de partida para el debate y la discusión de la Conferencia Intergubernamental, abierta en Roma el 4 de octubre de 2003, que fracasó en Bruselas el 13 de diciembre de 2003 y que por fin consiguió su objetivo en la cumbre de dicha ciudad el día 18 de junio de 2004.

Esta Conferencia Intergubernamental era el ente jurídico con competencia para la aprobación, por unanimidad, del nuevo Tratado, en una segunda fase. La única novedad del procedimiento respecto a los casos anteriores ha consistido en que, convencidos de que se había agotado el método diplomático, se decidió encomendar los trabajos, previos a la C.I.G., a un órgano novedoso, llamado Convención que añadió claridad y transparencia a los trabajos previos, pero no legitimidad democrática. Esta Convención, a pesar de su nombre no es la Convención de Filadelfia; tampoco estamos ante ningún proceso constituyente típico o clásico y el texto elaborado no puede ser una Constitución en el sentido que al término damos los constitucionalistas en cuanto normas supremas de los estados soberanos (Constitución «inédita» en términos de $\mathrm{P}$. CRUZ).

Se trata, nada más y nada menos, que de reformar el Tratado de Niza, cuyo procedimiento de reforma está previsto en el art. $48 \mathrm{del}$ 
TUE. Las modificaciones efectuadas deben ser hechas de común acuerdo, aprobadas por unanimidad y ratificadas por todos los Estados miembros de conformidad con sus respectivas normas constitucionales. El ente competente para aprobar las reformas es la Conferencia de los representantes de los Estados miembros convocada por el Presidente del Consejo. A la luz de lo dicho previamente los dueños y señores de los Tratados siguen siendo los Estados miembros. Pues bien, observamos que en su aspecto formal este proceso se desarrolla de la misma forma en que se realizaron las reformas previas en el seno de la Unión Europea. Pero, sucede que, desde una perspectiva material en este Tratado se ha plasmado "la dimensión constitucional» que el mismo Tribunal de Justicia de la Unión Europea ha atribuido al proceso de integración en una conocida jurisprudencia y que ha sido aceptada sin reticencias por un buen sector de la doctrina. Este hecho ha planteado en el seno de la academia una polémica recurrente acerca de la corrección de llamar CONSTITUCIÓN a la norma suprema de la Unión Europea: Existen serios peligros (ya fracasaron los Proyectos Spinelli y Hermann, en la década de los ochenta y noventa, respectivamente, para elaborar una Constitución Europea) de utilización de este término dadas las peculiaridades propias de la Unión Europea en cuanto organización internacional de carácter supranacional, que nos pueden inducir a utilizar el nombre de Constitución en vano (CARRERAS, RuIPÉREZ).

Por lo anteriormente expuesto la Convención se vio obligada a dar un alambicado nombre al nuevo texto: "Tratado por el que se establece una Constitución para Europa». En este título confluyen dos términos distintos: con la denominación de Tratado se alude al aspecto formal de la norma y con la denominación de Constitución se pretende dar cobertura a su contenido material y a satisfacer a un amplio sector de la doctrina. Ahora bien, el propio paralelismo de las formas impide entender que de la reforma de un Tratado Internacional, efectuada conforme al procedimiento establecido en el Tratado que se reforma, podamos obtener una Constitución normativa.

\section{EL TRATADO CONSTITUCIONAL A LA LUZ DE LOS PRINCIPIOS DEL MODERNO CONSTITUCIONALISMO}

Desde la óptica y los postulados del Derecho Constitucional se puede demostrar que la naturaleza jurídica de la norma en cuestión, su significado y alcance impiden entender que nos hallamos ante un Proyecto de norma jurídica que reúne las características propias de las Consti- 
tuciones surgidas del moderno Constitucionalismo que nace con las Revoluciones Francesa y Norteamericana de finales del Siglo XVIII. A partir de este momento histórico el objetivo de toda Constitución (en cuanto la forma última de organización del poder político, J. PÉREZ RoYo) es crear las instituciones para controlar y limitar el poder político. Con ello se pretende liberar a los gobernados del poder absoluto de sus gobernantes y asignarles una cuota de participación en el proceso del poder político; Esto queda recogido con claridad meridiana en el Art. 16 de la Declaración de Derechos del Hombre y del Ciudadano de 1789.

Según lo establecido en esta norma para poder hablar de Constitución es necesario el principio de división de poderes y el reconocimiento y la garantía de los derechos de los ciudadanos. Así pues, por Constitución en sentido estricto sólo podemos entender aquella que se identifique con el concepto racional normativo (LOEWENSTEIN). Todas ellas deben obedecer a un sustrato teórico común: la confrontación entre los supuestos ideológicos del pensamiento político democrático, de tal manera que recogen el principio democrático (la teoría democrática del poder constituyente), el principio liberal (defensa de la libertad individual a través de la división de poderes y de las declaraciones de derechos), y el principio de la supremacía de la Constitución (sujeción de los gobernantes a la norma suprema y concordancia del derecho ordinario con dicha norma) (DE VEGA).

La Constitución basada en los principios antes enunciados es la norma suprema de un Estado. Éste es una formación política basada en tres elementos indispensables: pueblo, territorio y poder. El pueblo, quizás el más importante de esos elementos integrados no es una masa amorfa de individuos sino la colectividad organizada de los nacionales, que se halla constituida en una unidad indivisible; Es el elemento por excelencia del Estado, porque éste se identifica con el pueblo. Además el Estado necesita poseer un territorio propio de forma imprescindible, estableciéndose entre el Estado y su territorio una relación de «imperium» ó soberanía territorial. También el poder o potestad pública es un elemento básico que se ejerce sobre los individuos que forman parte de ese grupo nacional y que se encarga de tomar las decisiones necesarias para los intereses nacionales. (CARRÉ DE MALBERG, FRIEDRICH, FERRERO).

Dados los elementos previos podemos definir al Estado como: "Una comunidad de hombres fijada sobre un territorio propio y que posee una organización de la que resulta para el grupo, considerado en sus relaciones con sus miembros, una potestad superior de acción, de mando y de coerción». Esta definición no es aplicable a la actual Unión 
Europea porque, ésta no es un Estado, ni un super-Estado, ni una superposición de Estados, ni un "ornitorrinco" como ha dicho algún tratadista, ni tampoco un OPNI (objeto político no identificado) como la define J. Delors. Fue creada por el Tratado de Maastricht de 1992 y se trata de un concepto político y no jurídico porque hasta la fecha ha carecido de personalidad jurídica. Por ello, hasta el día de hoy, las relaciones entre el Derecho de los Estados miembros y el Derecho Comunitario se realizan en el marco establecido en los Tratados originarios de las Comunidades Europeas y en particular en el Tratado CE. De lo que no cabe duda es de que la Unión Europea es una organización internacional con peculiaridades propias: Creada por el TUE, con instituciones de la CE que le sirven de soporte y con competencias específicas en ciertos ámbitos que le permiten adoptar actos jurídicos propios (política exterior, seguridad común, cooperación policial y judicial...). (MANgas, URREA, CebadA).

Esta organización internacional que obedece a una asociación voluntaria de Estados, con base convencional, ha originado un proceso ingente de cambios en los Estados Constitucionales que participan en el fenómeno integrador europeo. Frente a las clásicas relaciones interestatales, basadas en el respeto del principio de soberanía estatal, surgen otras relaciones distintas en el seno de la Unión que se fundamentan en el traspaso de competencias desde los Estados miembros a las instituciones comunes que acarrean una merma de la soberanía estatal. Este ente supranacional, con capacidad de crear normas que inciden en la esfera jurídica de los nacionales de todos los Estados participantes, se nutre de la soberanía de los Estados que lo conforman y camina hacia la obtención de un grado de estatalidad que va en detrimento de los Estados miembros que cada vez son menos soberanos. Esta organización internacional que no es un Estado, ni puede serlo porque no tiene un pueblo propio (no hay un pueblo europeo, sólo pueblos de los Estados europeos) y tampoco un territorio porque regula y coordina actividades que se desarrollan en los límites territoriales de las nacionesEstado que lo componen, se va formando gracias a la transferencia del ejercicio, que no de la titularidad, de atribuciones de los Estados miembros que funcionan no con base al principio de separación de poderes y sí del de colaboración de funciones y causa una relativización del concepto de soberanía así como problemas de legitimidad democrática de las instituciones y serias dificultades a la hora del establecimiento de los correspondientes controles. Porque son las Constituciones nacionales las que sostienen la existencia de la Unión Europea en base al poder constituyente del pueblo de cada uno de los Estados que participan en la integración, no podemos permitir una quiebra ilimitada del prin- 
cipio de soberanía sin poner en peligro el principio democrático de la soberanía popular (Pérez Calvo, García Gestoso, Herrera, Pescatore).

\section{EL NOVEDOSO PROCEDIMIENTO DE REFORMA DEL TRATADO DE NIZA}

El Tratado de la UE fue adoptado en Maastricht en 1992 y modificado por el Tratado de Ámsterdam de 1997 y por el de Niza de 2001. Gracias a estas normas se han producido cambios relevantes en los Tratados Constitutivos, sobre todo en el Tratado de la CEE. Del Tratado de la Unión Europea se deduce una nueva estructura del sistema de los Tratados hasta entonces vigente, porque este Tratado "envuelve» a los Tratados constitutivos de las Comunidades sobre los que se asienta, se trata de un "Tratado de Tratados". La numeración de sus artículos con letras fue eliminada en la reforma de Ámsterdam que vuelve a la numeración clásica del sistema de números arábigos en el articulado.

La Unión Europea que actualmente tenemos se funda sobre las tres Comunidades existentes y los ámbitos en los que hay cooperación intergubernamental: la PESC y la cooperación judicial y policial entre los Estados miembros. Ambas políticas conducen a los objetivos de la Unión pero no utilizan instrumentos de integración sino de cooperación intergubernamental, por lo que permanecen al margen del sistema jurídico propio de las Comunidades, aunque participen del sistema institucional (A. MANGAS).

Por lo antes expuesto es necesario dejar claro que la UE no posee de forma clara personalidad jurídica internacional: es un ideal político, que tiene una entidad política, pero cuya realidad política y jurídica, económica y social se sustenta en las realizaciones conseguidas a través de las Comunidades Europeas que son lo único tangible de la actual Unión Europea; Se trata de una idea de síntesis del proceso de integración progresiva de pueblos y de Estados. Lo que no se discute es su vocación federal internacional a pesar de que se dude y discuta en torno a su personalidad jurídica internacional; Problema éste que quedó sin resolver en las C.I.G. de 1996 y de 2000 donde de forma expresa se rechazó la posibilidad de dotar expresamente a la UE de personalidad jurídica. Así pues, la Unión Europea como ente político es el todo; Las Comunidades Europeas y las formas de Cooperación intergubernamental (PESC y la cooperación judicial y policial) son los pilares sobre los que se sustenta el proceso en su conjunto, sólo que ahora se le cambia la denominación por el nombre de "Unión Europea». Teniendo en cuenta la indefinición jurídica y política del momento presente ante 
la UE vigente hemos de constatar que el proceso de construcción europea, en cuanto inacabado, sigue abierto (ALDECOA).

La Declaración n. 23 anexa al Tratado de Niza organizó un debate, que no ha terminado todavía, sobre el futuro de la Unión Europea y las conclusiones del Consejo Europeo de Laeken (diciembre de 2001) acerca del horizonte final de este proceso. En dicha Declaración se sientan las bases para la reforma del modelo de la Unión y su transformación en otro modelo que responda a las necesidades derivadas de la ampliación de sus miembros y de la sociedad internacional de la globalización. En esta fase la democracia vuelve a ser la condición estructural predominante porque se pretende acercar Europa al ciudadano hacerla más transparente, más legítima y más comprensible. Lo novedoso en la reforma para conseguir esos objetivos (el procedimiento está fijado en el art. 48 del TUE) se halla en que la fase de preparación de la reforma se encomienda a un nuevo órgano que recibe el nombre de Convención Europea, órgano que en opinión de algún sector de la doctrina ha sido portador de forma implícita de "un mandato constituyente». EI antecedente directo de este proceso de cambio y modificación se encuentra en el Discurso de J. FISCHER, en la Universidad Humboldt de Berlín, en mayo de 2000. Apelaba el ministro verde a la recuperación del espíritu de la Declaración Schuman de 1950 que intentaba construir una Federación Europea y que sería beneficioso en la reflexión sobre el futuro y la finalidad de Europa antes de la ampliación. En esos momentos de bajo ánimo, porque no se habían podido consensuar las reformas necesarias en las dos últimas C.I.G., el discurso de Fischer obligó a los líderes europeos a manifestarse dialécticamente a favor de fórmulas intergubernamentales o de ideas federalistas. Lo novedoso es que casi todos, sin estar de acuerdo en su alcance y significado, se pronunciaron a favor de fórmulas federales; sí hubo consenso en que ante el desgaste del método intergubernamental, el método federal para la integración europea podía ser una garantía de eficacia (J. V. LoUIS, M. Barnier, la Pergola, Ruipérez, Mangas...)

Pero, aunque nos cueste admitirlo y a pesar de que la UE adquiere naturaleza política y se aleja cada vez más del modelo de organización internacional originario, se sigue manteniendo el método de reforma propio de una organización internacional clásica (el método diplomático, mediante una Conferencia Intergubernamental). Por ello se insiste tanto en el "déficit democrático" por la falta de transparencia y control de la negociación. Este hecho le hace al Parlamento Europeo considerar agotado el método diplomático de reforma y pedir que en las próximas modificaciones de los Tratados el procedimiento sea distinto. La debilidad y escasa eficacia del método diplomático se apreció con claridad 
meridiana en la C.I.G. de 2000 que convivió en el tiempo con la CONVENCIÓN que redactó la Carta de Derechos Fundamentales de la UE. Destacó la eficacia y la transparencia de este segundo método de trabajo que será el adoptado por la Declaración $n .^{\circ} 23$ anexa al Tratado de Niza para debatir de cara a la siguiente reforma.

Así las cosas, nos encontramos con la siguiente aporía: jurídicamente, al estar vigente el art. 48 del TUE es la CIG quien tiene la facultad de aprobar la reforma de los Tratados, pero, políticamente la CONVENCIÓN era el ente que estaba en la mente de los políticos, académicos, Estados miembros... como el más adecuado para efectuar las modificaciones indispensables. Como la Convención no podía sustituir a la CIG se adoptó un procedimiento en dos tiempos: primero será la Convención Europea la encargada del estudio y la elaboración de las propuestas que elevará a la $\mathrm{CIG}$; y en un segundo momento le correspondería a ésta pronunciarse con carácter definitivo sobre las propuestas de reforma efectuadas por la Convención; La naturaleza híbrida de la Convención Europea (parlamentaria e intergubernamental) produjo un documento sobre el que se ha discutido mucho: formalmente sigue siendo un Tratado con un contenido especial que le permite ser calificado como "constitucional" y que responde al modelo de la integración europea, el federalismo intergubernamental. Por todo ello, el Tratado por el que se establece una Constitución para Europa asume desde el principio un carácter híbrido pues, en opinión de la mejor doctrina comunitarista, sigue siendo un Tratado Internacional a suscribir por las partes contratantes, pero que en su contenido material se aprecia el deseo de que funcione y sea una "Constitución para los ciudadanos de la Europa Unida» (MARTín y Pérez de NANCLARES).

\section{LA AUSENCIA DE UN PODER CONSTITUYENTE EUROPEO: LOS ESTADOS SEÑORES DE LOS TRATADOS}

A pesar de las apuestas doctrinales de algunos constitucionalistas y de los elementos constitucionales que los comunitaristas encuentran en el Derecho originario de la UE, hemos de sostener que en la Europa Unida todavía no se cumplen en su plenitud los principios que inspiran el moderno constitucionalismo: el principio democrático, el principio liberal y el principio de supremacía de la Constitución. A finales del siglo XVIII y gracias al proceso de desacralización del Estado, surge la creencia de que al ser éste una obra humana, es al pueblo a quien le corresponde establecer sus modos y formas de organización. El principio democrático surge unido de forma inescindible al principio de sobera- 
nía popular que se erige en elemento nuclear de la nueva forma de organización política, el Estado; El documento de gobierno ha de ser expresión de la voluntad soberana de un pueblo que es el único sujeto legitimado para decidir la forma en que desea ser gobernado. Esto se realiza a lo largo de un proceso constituyente o de elaboración de una Constitución en el cual se verifican tres momentos diferenciados que ya en 1717 fueron teóricamente formulados por el reverendo J. WISE: Declaración de derechos, pacto social y acto constitucional. Si el reconocimiento de una esfera de libertad absoluta se concreta en las Declaraciones de Derechos, la garantía de los mismos sólo se consigue cuando, una vez aprobada la Constitución el Estado se organiza en base al principio de división de poderes. El pacto social se realiza de manera conjunta con el acto constitucional en el momento en que las Declaraciones de Derechos, que son previas, se incorporan en calidad de parte dogmática a los Textos Constitucionales. Este momento es esencial para determinar quien es el soberano pues, una vez que los individuos a través de su adhesión al pacto social consienten en formar el Estado culminan un proceso en el cual cada individuo cede su parte de soberanía a favor de una entidad nueva que los engloba: El Pueblo que queda como único titular de la soberanía en el Estado y el único capaz de establecer y sancionar la Constitución. La concreción de ese pacto social no sólo tiene lugar en el momento de fundar ó crear un Estado nuevo, sino que también puede darse en el marco de los Estados ya creados cuando se produzcan situaciones revolucionarias. Por lo antes expuesto constatamos que el poder constituyente es un poder político existencial que brota de forma espontánea de la Comunidad que decide darse una Constitución y cuya actuación no puede quedar constreñida por los límites estrechos de unos derechos que encuentran en él su fuente última, ni tampoco por un ordenamiento jurídico anterior a su propio nacimiento (M. KRIELE, Althusius, Stein...).

Porque esto es así el principio democrático es el elemento central de cualquier edificio constitucional y de su cumplimiento depende la existencia de una "Constitución Europea» en su sentido técnico, moderno y actual. Si tomamos como guión el trazado por WISE en 1717 comprobaremos que aún no se han verificado los distintos momentos del proceso constituyente en la Unión Europea. Sostenemos pues, que la concepción liberal del mundo entiende que el punto de arranque para la creación de una comunidad política era el reconocimiento de la existencia de una esfera de libertad individual absoluta en la que el Estado sólo entraría para asegurar a los burgueses el pleno disfrute de sus derechos, los cuales además de ser reconocidos deberían estar identificados y proclamados en un documento escrito, solemne y formal. A 
este fin obedecieron la Declaración de Derechos del Hombre y del Ciudadano de 1789 ó el Virginia Bill of Rights de 1776. Esos documentos se convirtieron en la base y fundamento de la actuación del Poder constituyente que se vería limitado por los márgenes trazados en esas Declaraciones de Derechos. Hasta la fecha en la UE no se ha producido el momento de la libertad, porque no se ha llevado a cabo la redacción y aprobación de un documento que responda a la filosofía de las Declaraciones citadas. Aunque existen algunos documentos jurídicos relativos a derechos como el Convenio Europeo de Derechos Humanos de 1950, la Carta Social Europea de 1961, la Carta Comunitaria de los Derechos Sociales Fundamentales de los Trabajadores de 1989. Y, actualmente, la Carta de los Derechos Fundamentales de la UE, solemnemente proclamada en Niza el 7 de diciembre de 2000 y que ahora entra a formar parte del Tratado Constitucional (parte II). Todos estos textos gozan del valor que les corresponde a las Declaraciones Internacionales de Derechos (art. 10.2 de la CE) que actúan como elementos para la interpretación de las normas constitucionales declarativas de derechos pero que por sí mismas carecen del valor de norma jurídica vinculante y directamente aplicable.

El segundo momento del proceso constituyente es el pacto social que tampoco se ha cumplido hasta el momento presente en la Unión Europea. El europeísmo se ha venido concretando en el deseo de establecer una unidad jurídica política y económica entre los Estados miembros pero, conservando su individualidad como unidades de decisión y acción política. El problema se plantea de cara al futuro cuando analizamos el Tratado Constitucional; según esta norma en dicho Tratado el sujeto constituyente es doble (los Estados por un lado y los ciudadanos por otro y del pacto de ambos surge la "Constitución» - Art. 1). En esta afirmación hay algo que carece de fundamento: La Convención y dentro de ella el Praesidium redactan por encargo del Consejo Europeo de Laeken un Proyecto de Constitución antes del nacimiento del poder constituyente, al que además se identifica. El intento de someter al futuro constituyente europeo que por definición habría de presentarse como un poder total, absoluto, soberano e ilimitado no sólo en el contenido de su voluntad sino también en la forma de su ejercicio choca con la naturaleza de "res facti, non iuris" que define al Poder Constituyente y que, a la postre, se traduce en la imposibilidad de que éste se encuentre circunscrito por las decisiones de unos órganos previos a él y en base a un ordenamiento jurídico anterior a su propio nacimiento.

A la vista del Tratado Constitucional nos preguntamos si existe ya o va a surgir un único pueblo europeo que se convierte en titular de la so- 
beranía. La respuesta no puede ser positiva, porque la Convención que ha redactado dicho Tratado no es la de Filadelfia; de ella sólo ha tomado el nombre. Pues bien, cuando en Filadelfia los representantes de los distintos pueblos acuerdan crear una única comunidad lo que hacen es renunciar a su individualidad como pueblos diferenciados para integrarse en una unidad política superior y única: el Pueblo de los EEUU de América. Los padres fundadores actuando en nombre de esa nueva colectividad elaboraron y discutieron la Constitución de Filadelfia que posteriormente fue sancionada y establecida por el propio pueblo de los Estados Unidos, en cuanto titular de la soberanía.

Comparando ese proceso con el actual observamos que en Europa no se ha verificado el pacto social y tampoco es evidente la voluntad de que vaya a producirse en un futuro inmediato, porque los distintos pueblos estatales no desean renunciar a su individualidad y trasladar su soberanía a una nueva entidad política: el pueblo europeo. Buena prueba de ello es el fracaso de la Cumbre de Bruselas de diciembre de 2003 donde a través de la actuación de los Jefes de Estado y de Gobierno se hizo patente el deseo de seguir manteniendo una identidad diferenciada en el marco de una "Europa unida en la diversidad" que seguirá teniendo una naturaleza internacional insoslayable (RODRíGUEZ IgLESIAS, DíEZ DE VELASCO, MANGAS...).

De esta forma ante la inexistencia de un pueblo europeo, la autoridad superior Ilamada a elaborar, discutir y aprobar el nuevo documento de gobierno de la Unión Europea son todos y cada uno de los Estados que la integran. Pero esa autoridad superior no es un poder constituyente porque, éste solo puede nacer cuando, como consecuencia del pacto social surge una nueva colectividad, el Pueblo como ente unitario, que se sabe soberano y que es el único legitimado para decidir el modo y la forma en que va a ser gobernado. El Tratado "Constitucional" debe ser entendido como un Tratado Internacional en la línea de los Tratados Fundacionales, que pese a sus defectos apreciables no es otro Tratado más en la construcción de la Europa unida en la diversidad, pero, pensamos que tampoco será el último texto para llegar a conseguir los objetivos deseados, pero nunca prometidos.

\section{EL PRINCIPIO LIBERAL COMO SISTEMA DE GARANTÍAS DE LA DEMOCRACIA}

Si el principio democrático condiciona la construcción del edificio constitucional, el principio liberal se presenta como el sistema de garantías que condicionan la idea de democracia. Los dos grandes su- 
puestos de la concepción liberal del mundo, el principio de la división de poderes y el reconocimiento de los derechos y libertades del individuo, suponen los cimientos de toda la construcción constitucional. (Art. 16 de la DDHC de la Revolución Francesa). Así pues, si no podemos definir la Constitución sin mencionar la división de poderes tampoco se puede abordar el tema de los derechos fundamentales sin tomar en consideración la posición que cada uno de los poderes del Estado ocupa en relación con los mismos. E incluso no pueden ser objeto de análisis los regímenes políticos sin tener en cuenta que son varios los poderes que tienen que ser combinados para que un régimen político democrático funcione o sea operativo. Esto se origina porque en el Estado Constitucional la soberanía estatal excluye toda competencia en el ejercicio del poder; $Y$ como el poder único puede convertirse en instrumento de opresión, es preciso el principio de la división de poderes para mantener la libertad conseguida.

Si trasladamos este esquema al supuesto de la Unión Europea observamos que el principio de la división de poderes deja mucho que desear, porque el sustrato de funcionamiento de esta organización supranacional es el principio de colaboración de funciones (QUERMONNE). De aquí el reiterado y manido "déficit democrático" de que se le acusa, aunque el poder aparece repartido entre distintas instituciones; El problema se presenta porque hasta el Tratado de Maastricht el efecto dominante estaba en que se gobernaba de espaldas a los ciudadanos de la Europa unida; o sea, que aunque las Comunidades no "han sido democráticas" el poder está y estaba dividido y ningún órgano ha logrado monopolizarlo, pero, esa dispersión del poder no se ha hecho conforme a los postulados del principio liberal. Cualitativamente hablando no se puede establecer una comparación entre la división de poderes de las Constituciones democráticas y la cooperación y participación de varias instituciones en una misma función o competencia de las Comunidades Europeas. Las funciones de decisión y control están separadas pero no lo están las instituciones que las realizan, ya que en la organización internacional objeto de estudio varias instituciones pueden concurrir en una misma función y además las denominaciones de las instituciones no se corresponden con las funciones estatales. El funcionamiento del sistema institucional comunitario es muy complejo y original debido al proceso continuamente abierto que integra no sólo a los Estados que siguen siendo soberanos, sino también a los pueblos de esos Estados (Janer Torrens, Ruíz-Jarabo, Martín...).

Así, el Consejo de la Unión comparte en numerosos ámbitos el poder legislativo con el Parlamento Europeo, aunque el Consejo representa los intereses de los Estados y el Parlamento los de los ciudadanos 
de la Unión, ambas instituciones representan las dos ramas del poder legislativo. Sin embargo, por el momento los legisladores comunitarios carecen de iniciativa legislativa directa aunque subsidiariamente pueden solicitar Proyectos a la Comisión, de quien representando los intereses de la Unión depende el inicio de toda norma jurídica en las Comunidades Europeas. Además de ser colegislador, el Consejo es el titular de amplios poderes ejecutivos por lo que adopta normas generales o de base y también en casos justificados, las de ejecución o, en su caso, puede atribuir la ejecución a la Comisión bajo ciertas modalidades de seguimiento o control; en estos casos el Parlamento Europeo también se desprende de poder normativo sin gozar del mismo control. Así las cosas, el poder ejecutivo en las Comunidades Europeas se reparte entre el Consejo y la Comisión que desde el Tratado de Maastricht ya no tiene la competencia exclusiva de velar por el cumplimiento de los Tratados y es el Banco Central Europeo el ente que asume esa tarea de supervisión y guardián en el aspecto monetario.

En conclusión: En el ejercicio de los tres poderes clásicos en el ámbito comunitario pueden concurrir varias instituciones que ejercen funciones de muy distinta naturaleza. Las interrelaciones que se dan convierten la colaboración en algo continuo y necesario además del respeto al sistema de pesos y contrapesos establecido. El fundamento del éxito del sistema y la clave de bóveda ha sido el principio del equilibrio institucional. Los fundadores de las Comunidades Europeas optaron por esta organización peculiar porque querían evitar cualquier emulación estatal y porque deseaban superar las reticencias que hicieran fracasar un Tratado indispensable en sus orígenes para la paz de Europa. De esta colaboración de funciones resulta un sistema de gobierno muy peculiar que no podemos calificar de Parlamentarismo porque éste no se ha desarrollado; sólo se dan relaciones de censura y confianza entre el Parlamento y la Comisión, y el Presidente de ésta, hasta ahora, no era votado por el Parlamento. El control parlamentario sobre la Comisión se efectúa a través de preguntas y comisiones de investigación. Los Consejos Europeo y de Ministros están en una posición tan elevada que prácticamente no pueden ser controlados por el Parlamento y las relaciones que este órgano mantiene con ellos no tienen relevancia. Respecto a la forma de Estado, siempre se ha dicho que la Comunidad Europea nació con vocación federalizante y que esa idea se mantiene en la Unión Europea que según los expertos se organiza conforme a los esquemas del federalismo que desplazó al originario funcionalismo y que se asienta en el principio del consentimiento.

El proceso inacabado sigue abierto y una vez consolidada la unidad económica y en parte jurídica, se ha comenzado la fase de unidad po- 
lítica; La Europa Unida se nos presenta como una organización de Estados cuya verdadera naturaleza jurídica no es fácil determinar porque, si bien es cierto que se organiza conforme a la técnica del federalismo, hoy por hoy no responde de manera exacta ni al concepto clásico de Estado Federal ni al de la Confederación de Estados aunque tenga rasgos de ambos (en lo que a la modificación de sus normas se refiere y a la eficacia de las normas jurídicas emanadas de los órganos centrales de la Unión de cara a los ciudadanos aparece como una realidad intermedia y equidistante de la Confederación y del Estado Federal) (LA PeRgola, RuIPÉREZ).

Por lo que respecta a las competencias las que posee la Comunidad son habilitaciones específicas para hacer algo concreto y aunque los fines de esta organización internacional sean muy extensos no dispone de todos los poderes necesarios para lograr sus objetivos. Luego, las competencias comunitarias (de las que goza gracias a los supuestos de quebrantamiento constitucional que las Constituciones de los Estados miembros prevén —como el art. 93 de la CE-) son específicas, limitadas y expresas. Carece de competencias propias y originarias y la forma híbrida de la Comunidad Europea impide el efecto mimético de los Estados Federales. La Unión Europea que engloba a las Comunidades Europeas actualmente es un ente político atípico que no tiene en el horizonte sustituir a los Estados soberanos que se han asociado para hacerla nacer a la vida jurídica.

Además del postulado de la división de poderes el liberalismo democrático considera imprescindible el reconocimiento de los derechos y libertades del individuo en toda construcción constitucional. Esos derechos fundamentales debían ser reconocidos y garantizados en la Constitución, sobre todo frente a los poderes públicos. De esta suerte, de la concepción de la democracia como simple ejercicio del poder por el pueblo se pasa al entendimiento de la democracia como garantía de la libertad. Sucede, en cambio, que los Tratados Constitutivos de las Comunidades Europeas no contienen ni un catálogo global de derechos ni un específico sistema de garantías. Se debió al momento histórico fundacional y a dos cuestiones de relevancia especial: la perspectiva económica de los Tratados y el fracaso político de la Comunidad Europea de Defensa (1952) y de la Comunidad Política Europea (1953). El silencio de los Tratados fue deliberado (RASMUSSEN) porque los autores de los Tratados optaron por dejar a los sistemas jurídicos nacionales la protección necesaria a los ciudadanos contra las intrusiones ilegales de la Comunidad en la esfera de dichos derechos. Incluso un catálogo de derechos reconocido de forma expresa en aquel momento hubiera obligado a plantear el tema espinoso de la primacía del Derecho Co- 
munitario que tampoco está previsto en los Tratados. Es decir que si los actos de las instituciones comunitarias aparecieran como actos de un legislador que debiera observar un catálogo de derechos, con todas las connotaciones constitucionales que ello conlleva, el tema de las relaciones Derecho Comunitario-Derecho Interno hubiera salido a la luz pública con mucha más fuerza desde el principio. El tema fue planteado posteriormente en términos de contraste entre la protección que expresamente se fija en las Constituciones Estatales y el silencio de los Tratados. Por ello el TJCE se vio obligado a construir una protección de los derechos a partir de las reclamaciones de los particulares que alegaban su derecho constitucional para intentar invalidar determinados actos de derecho comunitario (PESCATORE).

Fue la práctica del Tribunal de Justicia, que de una fase inhibicionista pasó a otra proteccionista de derechos, la que estableció que los derechos fundamentales forman parte integrante de los principios generales del derecho cuyo respeto garantiza el TJCE. La década de los años sesenta, al consolidar los principios de autonomía, eficacia directa y primacía del ordenamiento comunitario, hizo afrontar con mayor rapidez el problema de la protección de los derechos a partir de la Sentencia STAUDER. La metodología utilizada para integrar dicha afirmación en el Derecho Comunitario consiste en recurrir a las tradiciones constitucionales comunes de los Estados miembros y a los instrumentos internacionales de protección de los derechos humanos, sobre todo el Convenio Europeo de Derechos Humanos (PI Y LLORENS).

La legitimación general es necesaria pero no suficiente para la utilización de reglas externas al ordenamiento comunitario a la hora de proteger los derechos fundamentales de los ciudadanos de la Unión y la base legal que permite al TJCE la utilización de unos principios generales no escritos la encontramos en el art. 6.2 del TUE (antiguo F.2) que dice:

"La Unión respetará los derechos fundamentales tal y como se garantizan en el Convenio Europeo para la protección de los Derechos Humanos y de las Libertades Fundamentales firmado en Roma el 4 de noviembre de 1950 y tal y como resultan de las tradiciones constitucionales comunes en los Estados miembros como principios generales del Derecho Comunitario».

La referencia al CEDH tiene únicamente un valor de guía para el TJCE que tiene un elevado margen de maniobra. Al existir un catálogo codificado las pautas que el Tribunal de Luxemburgo sigue son más claras que en el caso de las tradiciones constitucionales comunes. La referencia al CEDH ha sido y es un factor clave para la identificación de 
los derechos fundamentales pero al no formar parte del Derecho Comunitario, el TJCE puede realizar una configuración propia de los derechos reconocidos en el mismo sin estar obligado a seguir en detalle la interpretación que al respecto hayan realizado los órganos de Estrasburgo. La inexistencia de un catálogo de derechos y de las correspondientes garantías específicas obliga a concluir que actualmente en el seno de la Unión Europea el reconocimiento por parte del TJCE se hace mediante los recursos previstos en los Tratados para garantizar, en general, el respeto del Derecho Comunitario, especialmente el recurso de anulación cuyo acceso a los particulares es muy restringido, y también con la cuestión prejudicial del Art. 234 del TUE.

Las cosas no cambiaron con el Tratado de Ámsterdam de 1997 que al reformar el Tratado de Maastricht aportó muy pocas novedades en materia de Derechos Fundamentales. Fue el acuerdo del Consejo Europeo de Colonia de junio de 1999 el que tomó la decisión de elaborar una Carta de Derechos Fundamentales que pusiera de manifiesto entre los ciudadanos de la Unión, de forma clara y visible sus derechos fundamentales vigentes, su significado y alcance, en cuanto exigencia de la actual evolución de la Unión Europea. Ahora bien, la Carta de Derechos de la Unión Europea no se inserta en un proceso constituyente que se haya abierto en la UE (RODRígUez BEREIJO); no obstante, es un paso adelante en el proceso político de construcción de la Europa Unida porque supera la mera visión economicista de esta organización internacional y mira hacia la Unión y los ciudadanos de los Estados que la integran como una entidad política fundada en valores comunes, en la que el respeto y la protección de los derechos fundamentales de la persona y los principios de la paz, la democracia y el Estado de Derecho constituyen sus pilares básicos.

El procedimiento de elaboración de la Carta fue fijado en el Consejo Europeo de Tampere de octubre de 1999 y como cuestión novedosa se encomendó dicha tarea a un órgano, autodenominado Convención, amplio y heterogéneo que utilizó un método de trabajo complejo a caballo entre el procedimiento "intergubernamental" y el procedimiento "parlamentario" tratando de encontrar, mediante el consenso soluciones de compromiso. El punto débil del proceso fue el problema espinoso de la naturaleza jurídica de la Carta que había quedado abierto en el Consejo Europeo de Colonia. Este documento que consta de un Preámbulo y 54 artículos, muestra los derechos sin destruir la Unión (RUBIO LLORENTE), pero no crea ninguna competencia ni objetivos nuevos para la Comunidad y para la Unión, ni modifica las competencias y los objetivos definidos por los Tratados (P. CRUZ). 
Finalizados los trabajos de la Convención el Tratado de Carta fue sometido a la consideración de los Jefes de Estado y de Gobierno en la Cumbre de Biarritz, en octubre de 2000. Su contenido no fue cuestionado pero los 15 Estados miembros se dividieron en torno al problema de su obligatoriedad. Por ello, en la Cumbre de Niza, al margen del Consejo Europeo, el 7 de diciembre de 2000, los Presidentes del Consejo, del Parlamento Europeo y de la Comisión, proclamaron conjuntamente al CDFUE. Y a esto quedó reducida: Se trata de un texto político, como lo fue la DDHC de 1789, sin valor jurídico, de momento. Dicho valor, que la doctrina reclama, se hubiera conseguido con una revisión del art. 6.2 del TUE añadiendo una referencia a la Carta como expresión máxima de los derechos que la UE se compromete a respetar (PÉREZ VERA). No hubo consenso y al reducirse ésta a una declaración política programática mantenemos que en la UE del Tratado de Niza, vigente, el momento de la libertad desde la Teoría Democrática del Poder Constituyente, aún no se ha producido.

Fue el Consejo Europeo de Laeken de diciembre de 2001 el que designó otra Convención encargada de dar respuestas de naturaleza constitucional a las cuestiones más relevantes sobre el futuro de la UE. Así, de cara a la C.I.G. que se abrió en Roma en otoño de 2003, entre otras cuestiones, esa segunda Convención tenía como objetivo n. ${ }^{\circ} 4$ la adopción de un texto constitucional que debía incorporar, después de solucionar el tema de su naturaleza jurídica, la carta de los Derechos Fundamentales de la UE. El fracaso de la Cumbre de Bruselas de los días 12 y 13 de diciembre de 2003 ha hecho que de momento las cosas sigan como están. Se le quiere conceder un alcance "reconocedor" de los derechos preexistentes, atribuyéndoles un plusvalor que le viene dado por su propia estructura y conformación; Los derechos se clarifican y su conocimiento es más fácil. Sirvió para preparar el camino al Tratado Constitucional y aunque no se haya eliminado el déficit democrático de la UE al menos tiende a disminuirlo porque las autoridades comunitarias, al proclamar la Carta y luego introducirla en la Parte II del precitado Tratado, han limitado sus poderes al reconocer que se encuentran vinculados a la misma. Esos derechos tendrán carácter jurídico obligatorio cuando los poderes públicos de la Europa Unida apliquen el Derecho Comunitario, quizás a partir de 2007, cuando entre en vigor la norma internacional recientemente firmada. Pero, el grado de vinculatoriedad de esta norma, contenedora de principios que han sido positivados, no es comparable al que se desprende de una Constitución normativa (A. PACE). 


\section{EL TRATADO CONSTITUCIONAL Y EL PRINCIPIO DE SUPREMACÍA CONSTITUCIONAL}

El constitucionalismo significa básicamente un sistema de garantías frente a las posibles arbitrariedades del poder público, con lo que se pretende el sometimiento del gobernante a la ley. La redacción de las primeras constituciones modernas conlleva el concepto de ley suprema que obliga por igual a gobernantes y gobernados y origina un fenómeno sin precedentes con importantes consecuencias jurídicas y políticas (K. SCHMITT).

La consideración de la Constitución como ley suprema de un ordenamiento jurídico significa que se encuentra por encima de las leyes ordinarias que deben obedecer sus postulados para no adolecer de vicios de inconstitucionalidad. Políticamente hablando al estar el gobernante también obligado a respetar lo establecido en la Constitución, ésta se convierte en la máxima expresión de la autoridad del Estado y en obligado centro de referencia, lo cual significa la coronación histórica del principio democrático de la soberanía popular, del derecho, de la ley o de la Constitución (García de Enterría, De Vega, Rubio Llorente...). De este modo las legitimidades políticas toman una dimensión jurídica, determinando que gran número de los problemas que la democracia presenta deban ser planteados y resueltos en términos constitucionales (Kelsen, KRABbe). Pues bien, para evitar que los principios del moderno constitucionalismo democrático se incumplan en la práctica (Constituciones nominales o semánticas) es imprescindible que en los textos constitucionales se establezcan medios o instrumentos de garantía. Los principales medios de protección de la Constitución como norma suprema son actualmente la justicia constitucional y el procedimiento de reforma. Si la primera garantiza el carácter de súper ley, en sentido material, de la Constitución, la segunda lo hace en sentido formal; De ambos procedimientos se obtiene el concepto de Constitución como "norma normarum» o "lex superior» (P. DE VEGA).

Las modernas Constituciones donde se conforman estados sociales y democráticos de derecho encomiendan su defensa y garantía a órganos especializados que, en cuanto continuadores de la función del poder constituyente soberano, tienen encomendada la tarea de ser los supremos intérpretes de las Constituciones. En el caso español ese órgano es el Tribunal Constitucional regulado en el título IX de la CE y en su Ley Orgánica de 1979. Dicho órgano constitucional, a través de las competencias que le han sido atribuidas defiende los principios en que se basa el moderno constitucionalismo (PÉREZ TREMPS). 
También el procedimiento de reforma (Título $X$ de la CE) más agravado y difícil en el supuesto de modificar la Constitución que el que se requiere para modificar las leyes ordinarias, políticamente hablando, permite diferenciar el poder legislativo ordinario (poder constituido y limitado) del poder constituyente soberano y del poder de reforma (poder constituyente constituido) en relación al principio democrático de la soberanía popular. Y el órgano que decide si las interpretaciones constitucionales y sus formas son correctas es el supremo guardián de la Constitución; La justicia constitucional es la coronación del edificio constitucional en la actualidad (Pérez Royo, De Vega, Jiménez Campo).

Si trasladamos este esquema al ámbito de la UE apreciamos que el Derecho Constitucional no ha perdido su carácter basilar para la política del Estado en sus distintas manifestaciones: internas, internacionales y comunitarias. Y, en este sentido prácticamente todos los Tribunales Constitucionales de los Estados miembros niegan a la Comunidad la capacidad de dictar resoluciones o adoptar actos que atenten contra las bases de sus ordenamientos constitucionales. Hasta el momento presente la UE es fruto de desarrollo reciente de los órdenes constitucionales de los Estados cuya identidad no se ha puesto en duda. Y, debemos tener en cuenta que el sistema comunitario no se ha concebido como el sistema tradicional de una Constitución normativa, pero tampoco lo ha sido como una organización internacional tradicional. El carácter "sui generis" de la organización supranacional hace difícil su definición. Aunque ha sido el Tribunal de Luxemburgo el órgano que comenzó a dar la denominación de "Constitución» a los Tratados Constitutivos puede resultar muy peligroso extrapolar dicho concepto porque en el espacio europeo el término no se puede utilizar como lo entendemos en el espacio del Estado-Nación, principalmente porque la UE no es un Estado y porque el sistema de la Comunidad no es todavía autónomo de los sistemas constitucionales de los Estados miembros. Son los principios constitucionales de éstos los que marcan el nacimiento del ordenamiento jurídico comunitario. Todo este contexto jurídico nos lleva al campo de los controles que es el tema principal del postulado de la supremacía constitucional. En el marco de la UE, los Tratados constitutivos (derecho originario) y el recientemente aprobado Tratado Constitucional, ejercen la función de ley fundamental de la Comunidad y recogen de forma particular los mecanismos tradicionales de control constitucional: respeto a la ley en el ejercicio del poder que está dividido en varias instituciones y existencia de controles suficientes para garantizar el respeto mutuo; También el que los derechos de los individuos frente a los órganos del poder publico estén garantizados y protegidos (Alonso García, Carreras). 
Ahora bien, los mecanismos de control existentes no pueden, por sus peculiaridades, ser equiparados a los existentes en el marco del constitucionalismo democrático; los mismos se han convertido en «mecanismos autónomos" de control gracias a la actuación del Tribunal de Luxemburgo, pues no encontramos en ellos ningún paralelismo con la definición del orden comunitario establecido normativamente. Es decir, si entendemos que el derecho comunitario es autónomo cuando es constitucional (HESSE), echamos en falta un instrumento jurídico que materialice esta afirmación. Hasta el momento presente la vertebración del control sobre la normativa comunitaria se articula en torno a los mecanismos existentes en los Estados miembros y al Tribunal de Justicia de la Comunidad que se configura como el único y máximo intérprete del Derecho Comunitario (HÄBERLE).

Se echa en falta un mecanismo que asegure que el Tribunal de Luxemburgo en sus actuaciones no vulnera ningún principio fundamental. Se dejaron a un lado las propuestas surgidas en la primera fase de la Convención a favor de crear un Tribunal Constitucional que fuese competente para dilucidar las controversias en torno al principio de subsidiariedad y al reparto de competencias. De este modo el art. I-29 del Tratado "Constitucional" sigue otorgando al Tribunal de Justicia su función tradicional como garante del respeto del derecho en la interpretación y aplicación de la "Constitución». Este precepto obedece a la realidad de que el derecho de la UE es el producto del diálogo entre los actores de una amplia comunidad jurídica europea en la cual la opinión de alguno de esos actores puede ser opuesta a la del Tribunal de Justicia. Cabe preguntarse ¿debe estar este ordenamiento jurídico sujeto a una organización jerárquica que garantice al Tribunal de Luxemburgo ó a los Tribunales nacionales el papel de autoridad última a la hora de resolver los conflictos jurídicos en el seno de la Comunidad jurídica europea?. Aquí radica el problema de la soberanía jurídica en la Europa unida. Hasta el momento presente da la impresión de que el derecho comunitario es quien asume la autoridad última frente al derecho estatal (art. I-6 del Tratado Constitucional). Este fenómeno se asocia a la necesidad de encajar el derecho europeo con la estructura jerárquica clásica de los ordenamientos jurídicos que, por otro lado es atacada por la forma en que se lleva a cabo la integración europea. Pero, en realidad, tanto el derecho nacional como el derecho europeo asumen en su lógica interna el papel de derecho superior. Según el Tribunal de Justicia de la Unión, el derecho comunitario primario será el «derecho superior" de la Unión, criterio de la validez de resoluciones y normas secundarias, así como de todas las normas y resoluciones nacionales incluidas en su ámbito. El Tribunal Supremo de este ordenamiento es el 
Tribunal de Luxemburgo. En cambio, los Tribunales Constitucionales de los Estados miembros, los ordenamientos jurídicos y las Constituciones que defienden sostienen que el Derecho Comunitario debe su primacía a la recepción operada por una norma nacional superior, la Constitución, y donde radica el poder último de adjudicación jurídica es en los Tribunales Constitucionales nacionales (D. ChALMERS).

Por todo ello, la cuestión de "quién decide quién decide" tiene respuestas distintas desde la óptica europea o nacional y cuando se contempla desde fuera de ambos ámbitos obliga a entender que se trata de un ordenamiento jurídico que no se fundamenta en estructuras jerárquicas y en una idea de la soberanía como única e indivisible. Se trataría de la idea rompedora y desafiante de las soberanías en competencia que ha tenido sus defensores entre la doctrina y apoyo jurisprudencial suficiente en diversas sentencias (muy conocidas) de los Tribunales Constitucionales (POIARES).

Por lo que se refiere al tema de la Reforma Constitucional, en cuanto técnica que garantiza el carácter de superley en sentido formal de la "norma normarum» hemos de resaltar que en el caso de la Unión Europea dicho procedimiento se conforma de acuerdo a los cánones de la Convención sobre el Derecho de los Tratados o Convención de Viena de 1969, donde en su art. 1 se dice que es de aplicación a los Tratados entre Estados y donde en los arts. 39 y ss. se establecen los procedimientos de enmienda y modificación.

Para el supuesto concreto de la UE el art. 48 del Tratado de la Unión Europea es la norma vigente, redactada con un carácter muy rígido. La iniciativa la tienen el Gobierno de cualquier Estado miembro o la Comisión que deben presentar el Tratado al Consejo. Este, consultado el Parlamento Europeo, emitirá un dictamen para que siga el procedimiento su curso normal y a través de su Presidente convocará una Conferencia de los representantes de los Gobiernos de los Estados miembros para que de común acuerdo aprueben las modificaciones que deben ser ratificadas por todos los Estados miembros de conformidad a lo establecido en sus normas constitucionales. Una novedad relevante que introduce el Tratado por el que se establece una Constitución para Europa en este tema es que amplía la iniciativa al Parlamento Europeo y se sigue negando la misma a los ciudadanos; Se eleva a rango normativo la existencia de la Convención y se establece su composición, como instrumento de trabajo en la fase previa a la Conferencia Intergubernamental.

Una novedad que aporta el Tratado Constitucional, reiteradamente solicitada por la doctrina, es un procedimiento para la retirada volun- 
taria de la Unión por parte de un Estado miembro. Esto se fija en el art. I-60 del Proyecto de norma en cuestión. Esa decisión debe ser comunicada al Consejo Europeo y será negociada conforme al procedimiento previsto en el artículo III-325, apartado $2^{\circ}$. Se concluye en nombre de la Unión por el Consejo y deberá ser aprobada por el Parlamento Europeo. El Consejo Europeo debe tomar esa decisión por mayoría cualificada de sus miembros que representen, al menos, el $72 \%$ de los Estados y el $65 \%$ de la población. Si el Estado miembro que se ha retirado de la Unión solicita de nuevo su adhesión, su solicitud se someterá al procedimiento establecido en el Art. I-58.

De cara a futuras reformas del reciente Tratado Constitucional se ha previsto otra novedad relevante: si cuatro quintas partes - no la unanimidad- de los Estados han ratificado en el plazo de dos años el Tratado, y algún país no logra hacerlo, el Consejo Europeo decidirá qué es lo que hay que hacer, examinando previamente la cuestión (Art. IV443.4).

\section{LA INTEGRACIÓN EUROPEA COMO PROCESO ABIERTO}

A pesar del fracaso de la Cumbre de Bruselas, que demostró que no estamos preparados para la desaparición de los Estados soberanos, el barco de la integración Europea no ha naufragado y sigue su rumbo conforme al principio evolutivo que ha sido y es la clave de su éxito. En el estadio actual de evolución son necesarias grandes reformas para poder adaptar esta organización supranacional a la mayor ampliación sufrida a lo largo de los casi cincuenta años de su historia.

Para conseguir estos objetivos desde el punto de vista jurídico formal el Tratado "Constitucional" no parece introducir grandes cambios en relación con el momento presente, porque el nuevo Texto sigue siendo un Tratado Internacional regido por las normas de derecho internacional en cuanto a las condiciones de su entrada en vigor y a los requisitos para su modificación, por lo demás muy rígidos, en la medida en que se sigue exigiendo para su ratificación el consentimiento de todos los Estados miembros. La innovación en el uso del término "Constitución" pone de relieve la voluntad de establecer un texto que, por su función y contenido, tenga una naturaleza constitucional y "pueda" ser materialmente entendido como tal por el conjunto de los ciudadanos (Liñan, Martín y Pérez de Nanclares, Mangas...).

Otra novedad, aunque se sigue manteniendo el método intergubernamental, es la participación en la primera fase del procedimiento 
de reforma de un órgano novedoso, llamado Convención con precedentes en la elaboración de la Carta de Derechos, y que aunque no añade más democracia al proceso sí aporta claridad y transparencia, que no es poco.

A pesar de la imperfecciones técnicas, que las hay, se intenta en el Tratado dar respuesta a bastantes de las cuestiones que, de acuerdo con la Declaración de Laeken, debían ser abordadas en el debate constitucional. Cabe destacar al respecto: la desaparición de los pilares, la reforma de las instituciones, la definición de las competencias de la Unión de forma no rígida, el refuerzo del principio de subsidiariedad con el papel reconocido a los Parlamentos nacionales, la simplificación de los Tratados y del Derecho comunitario, la clarificación de la tipología de las normas y actos de las instituciones, la jerarquía normativa, la reforma y extensión de la mayoría cualificada, la generalización de la codecisión del Parlamento europeo, la atribución de personalidad jurídica a la Unión Europea en el Art. I-7 del Tratado, la incorporación con carácter vinculante al texto de la norma en análisis de la Carta de los Derechos Fundamentales de la Unión Europea y la confirmación del control jurisdiccional "a posteriori» del Tribunal de Justicia, con la pretensión de reconocerlo como Tribunal Constitucional de la Unión; asimismo, la transparencia, la comunitarización del espacio de libertad, seguridad y justicia, y la posibilidad de adhesión en el futuro al Convenio Europeo de Derechos Humanos y el desarrollo de la política exterior común.

Una cuestión que sigue presentando muchas dudas y sobre la que se insistió en la Declaración de Laeken es la de "más democracia, transparencia y eficacia en la organización institucional»; Consideramos que sigue siendo una asignatura pendiente. El asunto de los controles queda muy debilitado y esto es algo fundamental en democracia, aunque ésta resulta algo reforzada en la medida en que se fortalece el Parlamento Europeo en el equilibrio institucional y en su participación en el proceso legislativo. Respecto al funcionamiento de las instituciones será la práctica la que permita emitir un juicio sobre las modificaciones que se pretenden. Destaca una medida prevista en el Art. I-50.2 del Tratado Constitucional: la publicidad de las sesiones del Parlamento y las del Consejo de Ministros cuando examina y adopta propuestas legislativas. Sin embargo es una de las cuestiones que chocó con la oposición de la CIG de 2003, pero que finalmente salió adelante en la cumbre de junio de 2004.

Desde una perspectiva jurídica las modificaciones contempladas en el Tratado en cuestión son generalmente modestas. Pero después de 
haber sido aprobado y a la espera de que entre en vigor, una vez ratificado por todos los Estados miembros, previsiblemente antes del $1 .^{\circ} \mathrm{de}$ noviembre de 2006, bien a través de referendos o por medio de los Parlamentos nacionales, se hará visible el proceso de actualización de la Unión a las necesidades de un mundo globalizado y se reforzará la legitimidad de la Unión y de sus instituciones siempre que su funcionamiento en una organización supranacional que se aproxima a los treinta miembros sea satisfactorio.

En conclusión: El proceso de integración seguirá siendo un proceso abierto hacia dentro y hacia fuera para no hipotecar el futuro de generaciones venideras y sus objetivos permanecerán indeterminados jurídica y políticamente. El debate constitucional deberá continuar para hacer evidentes los postulados del moderno constitucionalismo en esta «Europa unida en la diversidad». Únicamente si los mismos se contemplan y se reconoce expresamente el principio democrático de la soberanía popular esta organización supranacional, de carácter internacional, seguirá construyéndose sobre las Constituciones de los Estados miembros y no sobre sus ruinas (J. RUIPÉREZ).

\section{EL DESBLOQUEO DE LAS NEGOCIACIONES}

El atentado terrorista del 11 de marzo de 2004 en Madrid, y el resultado electoral producido en las elecciones generales del 14 de marzo que, contra los pronósticos publicitados, concedieron el triunfo al Partido Socialista Obrero Español, han producido un cambio en la política exterior española. Se ha abierto la puerta a la posibilidad de que el Tratado Constitucional sea una realidad en breve plazo de tiempo.

Con fecha 11 de marzo de 2004, el mismo día del grave atentado terrorista en Madrid, la prensa (Cfr. El País, Pág. 2., Sección Internacional), publicaba que: "Irlanda propone un nuevo reparto de poder para resucitar el debate de la Constitución. España rechaza la fórmula mientras Polonia considera positivo que se reabra el diálogo". Irlanda, país que ocupaba la Presidencia de Turno - hasta el mes de junio de 2004-en la Unión Europea, fue el encargado de establecer los correspondientes contactos con los países miembros para desbloquear la situación en que permanecía el Tratado Constitucional desde el fracaso de la Cumbre de Bruselas del mes de Diciembre de 2003. En esas fechas, España y Polonia rechazaron la fórmula establecida en el Tratado Constitucional para el reparto de poder en el Consejo. El sistema de la doble mayoría, $50 \%$ / 60\%, propuesto por la Convención e incluido en el Tratado Constitucional permite que tres de los cuatro grandes países de la U.E., 
puedan bloquear cualquier acuerdo que pretendan alcanzar todos los demás, siempre que uno de los grandes sea Alemania que cuenta con 82 millones de habitantes. Si, por el contrario, tal y como propone la Presidencia irlandesa, se rebaja el umbral del $60 \%$ de la población al $55 \%$ de la misma, ninguna combinación posible de tres de los cuatro grandes países puede sumar el $45 \%$ de la población necesaria para la acción de bloqueo. En teoría este hecho debería haber sido bien recibido por España donde el Gobierno del expresidente Aznar siempre insistió en que el Tratado Constitucional da excesivo poder a los países grandes, porque tres de ellos tienen la llave para bloquear cualquier acuerdo. Sin embargo no fue así, y la fórmula del $55 \% / 55 \%$, (en lugar de la combinación $50 \%$ / $60 \%$ ), no se admitió porque se entiende que ese sistema le hace perder a España más poder aún del que ya cede en el Tratado Constitucional en relación con el vigente Tratado de Niza. La propuesta en cuestión no ha llegado a ser planteada de forma oficial, sino que se trataba de una alternativa, entre otras, para reabrir el debate bloqueado.

El giro copernicano del enfoque del problema y su posible solución se dio tras el cambio de Gobierno en España. Con fecha 17 de marzo de 2004 se presentó en Bruselas un artículo del Presidente Rodríguez Zapatero, titulado "En defensa de la Constitución Europea», en el que, entre otras cuestiones, se resalta el deseo de tener una "Constitución Europea" para el 2004. Con el ánimo de culminar una unión política en sentido federal; el PSOE es artífice del Tratado de "Constitución Europea" y se siente responsable del resultado de los trabajos de la Convención en cuyo seno participaron los socialistas Borrell, López Garrido, y Carnero. Todos ellos, en defensa de las ideas de su partido al respecto, se han mostrado defensores del sistema de la doble mayoría porque la misma está en relación con la base de cualquier democracia, es decir, los Estados y los ciudadanos. Este sistema facilita la toma de decisiones y obligaría a España a construir de forma inteligente mayorías de gobierno junto a otros socios en la Unión Europea. No obstante, siempre se dejó claro por parte de los socialistas el deseo de recuperar alguno de los catorce escaños de la Eurocámara que España perdió en el Tratado de Niza (descendió de 64 representantes a 50).

De este modo, el cambio de Gobierno en España permitió, en un contexto mucho más favorable, dar nuevo impulso a las negociaciones. Para ello, Ahern, Presidente Irlandés, convocó al Presidente Rodríguez Zapatero, a tratar sobre el Tratado Constitucional antes de la cumbre europea de los días 25 y 26 de marzo. Le correspondía a la Presidencia irlandesa presentar en esa cumbre de Bruselas un informe a los líderes europeos para explicarles, después de las correspondientes entrevistas, 
si se daban o no las condiciones adecuadas para convocar de nuevo la Conferencia Intergubernamental encargada de negociar el Tratado Constitucional que fue imposible cerrar en diciembre de 2003 por el rechazo de España y Polonia a la fórmula del reparto del poder incluida en el Tratado.

En la cumbre de Bruselas de finales del mes de marzo se colocó sobre la mesa la necesidad de negociar una nueva fórmula de reparto de poder para recuperar el Tratado Constitucional ya que no hay tanto tiempo para el debate como fuera deseable. Fue en esa cumbre, donde la Ministra española de Asuntos Exteriores, en funciones, Ana Palacio comentó que las conversaciones avanzaban en buena dirección, pero insistió en el "sistema de doble llave" propuesto en su día por la delegación española que trata de introducir elementos correctores en la fórmula de doble mayoría (50\% / 60\%), que incluye el Tratado y que España y Polonia rechazaron en diciembre de 2003 . Frente a la fórmula $55 \%$ / 55\% puesta en circulación por Irlanda y Alemania, que permite a un $45 \%$ de Estados bloquear la toma de decisiones aunque representen un porcentaje mínimo de población, o a tres o cuatro de los grandes países, en una Unión Europea de 25 miembros, se intenta introducir algunos elementos correctores que eviten las citadas distorsiones. Se trataría de añadir una segunda llave al sistema de la doble mayoría, y así por ejemplo, doce países podrían bloquear las decisiones, siempre y cuando representen al menos el $40 \%$ de la población; o los Estados que representen el $45 \%$ de la población podrían bloquear las decisiones cuando pacten alianzas entre un número "X" de países. Esto solo son ejemplos a tener en cuenta, pero, ya en Niza, Alemania impuso que una vez tomada una decisión, cualquier país pueda exigir que se compruebe que quienes la han apoyado representan al menos el $62 \%$ de la población: esto también es una segunda llave.

Aunque son fórmulas mucho más complejas que las propuestas en el Tratado Constitucional, las partes negociadoras pensaron que por esa vía podían encontrar con más facilidad un acuerdo. Esos acuerdos eran necesarios para todos los problemas pendientes, entre los que no pueden olvidarse la composición de la Comisión - se mantiene hasta 2014- (los Estados pequeños quieren un Comisario por país, y los Estados grandes desean un ejecutivo reducido), y el reparto de escaños en el Parlamento Europeo en el cual los países pequeños desean contar con, al menos, cuatro representantes. Finalmente se acordó que su composición no superase los 750 miembros. El número máximo será de 96 escaños y el mínimo de 6 por Estado miembro. En consecuencia, en la cumbre de Bruselas de los días 24 y 25 de marzo de 2004 se acordó reabrir las negociaciones del Tratado Constitucional a partir 
de la fórmula que España y Polonia rechazaron en diciembre de 2003. Tras la despedida del presidente Aznar, el triunfo socialista en España y la reacción positiva de Polonia al quedar aislada, se facilitó el camino para cerrar el "debate constitucional» en el mes de junio de 2004, antes de la cumbre europea de los días 17 y 18 . No hubo una propuesta única a debatir, pero se tuvo claro que el nuevo reparto de poder se debía pactar sobre la doble mayoría de Estados y de población continuamente rechazada por el expresidente Aznar y que siempre fue aceptada por los socialistas españoles. La defensa de los intereses nacionales de los 25 Estados miembros, pero sobre todo de los grandes, no hará de la negociación un camino de rosas, pero ahora todos están comprometidos a pactar la "Constitución" para que el funcionamiento de la Unión Europea sea más eficaz, más transparente, y más democrático. Este objetivo, inviable antes de la Cumbre de Bruselas del mes de marzo, consistió en pactar un Tratado Constitucional como instrumento para que la Unión esté mejor dotada a la hora de responder a las demandas de sus ciudadanos y para desempeñar un papel más eficaz en el mundo globalizado. En esto ha tenido mucho que ver la amenaza terrorista internacional subrayada por el grave atentado del 11 de marzo de 2004 en Madrid.

A partir del sistema de la doble mayoría el Presidente irlandés consideró posible un acuerdo equilibrado. Para resolver los problemas de la fórmula $50 \%$ / $60 \%$ contenida en el Tratado Constitucional se han ofertado otras propuestas: a Francia y al Reino Unido no les gustaba la de $55 \%$ / $55 \%$ propuesta por Irlanda y apoyada por Alemania, otras propuestas eran $55 \%$ / $65 \%$, 55\% / 64\%, y 50\% / 66\%. Esta última fue defendida por el expresidente Aznar en el mes de diciembre de 2003. Cuanto más elevado sea el porcentaje de población, más favorecidos resultarán los grandes países a la hora de poder bloquear, y cuanto mayor sea el porcentaje de países necesario para tomar decisiones, más fácil será para los pequeños establecer alianzas de bloqueo; pero a la vez, se deben fijar elementos correctores para ambos techos, porque ningún grupo de países podrá bloquear decisiones si no representa al menos un mínimo de población. Así se habla de una cifra mínima -entre cuatro y cinco países- para ejercer el bloqueo, y de un mínimo de población, entre el $15 \%$ y el $20 \%$. Este sistema, complejo y enrevesado, para tomar decisiones, siempre fue rechazado por el presidente de la Convención, Valery Giscard d'Estaing.

Pues bien, siguiendo el curso de los acontecimientos relatados, observamos que con fecha 1 de abril la Eurocámara aprobó una resolución para pedir al "Consejo Europeo que disponga la ceremonia solemne de la firma del futuro Tratado Constitucional en la ciudad de 
Madrid, como acto simbólico, con el fin de afirmar que la respuesta más eficaz al terrorismo y a su mensaje de miedo y de barbarie reside en la fortaleza de las instituciones europeas y en la promoción de un proceso de participación libre, civil y democrático". Frente a esta propuesta se alzan voces que reclaman dicha firma en Roma (Tratado de Roma II) y el Presidente Ahern propone que cada país miembro proceda a la firma en la capital de su respectivo Estado, sin perjuicio de una ceremonia posterior, solemne y conjunta. Al final la firma se llevo a cabo en Roma el 29 de octubre de 2004.

Los Ministros de Asuntos Exteriores de la Unión Europea, en su reunión en Luxemburgo el 26 de abril de 2004 aprobaron el calendario para la reanudación de las negociaciones sobre el futuro del Tratado Constitucional. El Presidente del Gobierno Español, en su día, dejó clara su voluntad de que se implantase el sistema de la doble mayoría, pero no se precisaron porcentajes ni se valoraron las distintas fórmulas en estudio. Se fijó la fecha de 17 de mayo para que los Ministros de Asuntos Exteriores reanudasen en Bruselas las negociaciones de cara a la aprobación del Tratado de Constitucional dentro del marco de la correspondiente Conferencia Intergubernamental. Esta dispuso de un mes para lograr un acuerdo sobre el citado Proyecto normativo para la Unión Europea puesto que, los Jefes de Estado y de Gobierno ya habían decidido que como muy tarde el Tratado debería quedar cerrado en la Cumbre de junio prevista para los días 16 y 17, una vez celebradas las elecciones al Parlamento Europeo que tuvieron lugar el día 13 de junio.

Los principales asuntos negociados en esa Conferencia Intergubernamental se centraron en el reparto de poder en el Consejo de la Unión Europea, en la Comisión y en el Parlamento Europeo. Tras el desbloqueo de las negociaciones y una vez aceptado el principio de la doble mayoría el debate se centró en discutir los porcentajes concretos y en fijar la fecha en que el Tratado Constitucional debía entrar en vigor. Pero se barajó otra posibilidad que consistía en aprobar el nuevo sistema de voto dejando abierta la posibilidad (durante unos años) de que un país miembro pudiera solicitar, en un caso concreto, que se emplease el sistema de voto aprobado en Niza en el año 2000 y que, al parecer, tan beneficioso es para España. En palabras de Moratinos, actual Ministro de Asuntos Exteriores en España: "los votos hay que defenderlos, pero el voto no es suficiente. Europa no se hace solo con votos, sino con influencias". 


\section{EL CONSENSO SOBRE EL TRATADO CONSTITUCIONAL.} LA CUMBRE DE BRUSELAS DE LOS DÍAS 17 Y 18 DE JUNIO DE 2004

El reparto de poder en la Unión Europea ha sido el gran escollo a superar a lo largo de los veintiocho meses de negociación del «Tratado Constitucional». La nueva fórmula de la doble mayoría para tomar decisiones en el seno del Consejo Europeo requerirá el concurso del 55\% de los Estados y del $65 \%$ de la población. Con dicha fórmula España obtiene más peso que el inicialmente concedido por el Tratado. Y Alemania se convierte en el país que más peso tendrá en la Unión, rompiendo la paridad existente hasta ahora entre París y Berlín en este aspecto. EI acuerdo final sólo se consiguió cuando se aceptó la introducción de cláusulas y prevenciones que han convertido a este fórmula en la más farragosa y enrevesada de toda la historia de la Unión Europea. Con la fórmula aprobada se intentan combinar intereses y opciones de bloqueo de unos y otros, ya que, con la combinación 55/65 sólo tres grandes países reúnen una población adecuada (más del treinta y cinco por ciento), para bloquear cualquier acuerdo. Ahora bien, para poder evitarlo se añade una cláusula: que el número necesario de países para bloquear decisiones sea de cuatro, y, además, también hará falta una coalición de quince países para poder aprobar las decisiones; las abstenciones no serán nunca tenidas en cuenta al realizar el cómputo de los Estados y la población. Se requiere incluso, cuando la propuesta que analice el Consejo no provenga de la Comisión o del Ministro Europeo de Asuntos Exteriores, que la mayoría cualificada sea del $72 \%$ de los Estados que representen, al menos, el 65\% de la población. Otro requisito: si una coalición de países que rechaza un acuerdo suma más del treinta por ciento de la población de la Unión Europea, o está compuesta por más del cuarenta por ciento de los Estados, el Consejo hará todo lo que esté en su mano para conseguir un acuerdo antes de votar. (Cláusula IOANNINA), que se introdujo para que Polonia aceptara la fórmula global. Y, por último, en aquellas reuniones del Consejo en las que no todos los Estados tienen derecho a voto, (por ejemplo, en las de Ministros de la zona euro), las combinaciones de 55/65 y 72/65 serán adaptadas y la minoría de bloqueo matemática por países tendrá que sumar una unidad.

Para España, esta fórmula compleja que entrará en vigor en 2009, al parecer es positiva porque se acerca a lo que exigía nuestro Presidente del Gobierno, que proponía la alternativa 55,5\% / 66,6\%. Al elevar finalmente el porcentaje de población al 65\% España tendrá más opciones de bloquear decisiones en áreas clave como puede ser la agricultura. Inglaterra ha conseguido también salvar en el "Tratado 
Constitucional» todas sus líneas rojas para mantener el derecho de veto en fiscalidad, seguridad social, política exterior o cooperación judicial penal, logrando rebajar enormemente los avances hacia la unión política recogidos en el Tratado. España y Polonia, responsables del fracaso de la cumbre de Bruselas de 13 de diciembre de 2003, han visto compensada su pérdida de poder respecto a Niza con cláusulas especiales, pero ni en el preámbulo, ni a lo largo del articulado, se hace referencia alguna a la herencia cristiana de Europa como pretendían PoIonia y otros Estados miembros. Tampoco hay novedades importantes respecto al uso de las lenguas, estableciéndose la traducción del Tratado Constitucional a las que sean cooficiales en algún Estado miembro, como sucede en España, con el catalán, vasco o gallego. Se acompaña también de una DECLARACIÓN del Reino Unido y España en la que se señala que: "la Carta Magna se aplica sobre Gibraltar en tanto que territorio europeo de cuyas relaciones exteriores es responsable un Estado miembro».

Pero, la pugna por el reparto de poder no se limitó al Consejo de la Unión Europea. Los otros dos frentes de batalla eran la Comisión y el Parlamento Europeo. Por lo que respecta a la Comisión, los países pequeños y los que acababan de incorporarse el día 1 de mayo del año en curso, consiguieron imponer a los demás que el Ejecutivo Comunitario tuviera un Comisario por país durante dos legislaturas más - cada una tiene una duración de cinco años-, es decir, hasta el 2014. En cambio, en Niza se establecía que a partir de la presente legislatura iniciada en noviembre de 2004, cada país tuviera un solo Comisario (los cinco grandes, entre ellos España, perderán el segundo que tienen ahora). La regla general se romperá cuando la Unión Europea tenga más de 27 socios, porque entonces pasará la Comisión a tener menos Comisarios que Estados miembros: los pequeños dispondrán de su Comisario hasta 2014, pero después de esta fecha la fórmula queda reducida a que el número de Comisarios coincida con los dos tercios de los países miembros.

También fueron muy complejas las conversaciones sobre la sustitución de Romano Prodi al frente de la Comisión. Es la primera vez que los líderes designan al candidato por mayoría cualificada, no por unanimidad, y en teoría, a la vista del resultado de las elecciones europeas, caracterizadas por un elevadísimo y preocupante grado de abstención, deberá ser un conservador. No se consiguió el deseado acuerdo el 18 de junio, y hasta finales del mismo mes no se perfiló un candidato de consenso. Este ha sido el Primer Ministro portugués, de centro derecha, J. M. Durao Barroso. 
El Parlamento Europeo, considerado como la institución ganadora en la reforma, también modificará su composición en los próximos años. Incrementa el número de eurodiputados respecto a los 736 del Tratado, hasta un total de 750; Alemania, el país más poblado, con 82 millones de habitantes, desciende desde los 99 escaños que le otorgaba Niza hasta 96 eurodiputados. Y los países menos poblados dispondrán, al menos, de 6 escaños en la eurocámara. Esto fue lo que exigió el incremento del número de escaños en 14; es en esta línea donde España podrá basarse para recuperar entre 4 y 5 de los 14 diputados europeos que se perdieron en el Tratado de Niza. El Parlamento Europeo incrementa también su número de competencias, configurándose como colegislador con el Consejo y atribuyéndose la elección del Presidente de la Comisión que será quien le ponga cara al texto recientemente aprobado.

A partir del 18 de junio se ha dado luz verde a un texto farragoso y de difícil comprensión para el ciudadano, con 448 Arts. 36 Protocolos, dos anexos y 48 Declaraciones, pero que entre sus principales aportaciones incluye:

A) Una opción de incremento de la democracia con una mayor transparencia en las actuaciones y reconociendo al ciudadano europeo como pilar de la Unión dando fuerza jurídica a la Carta de Derechos Fundamentales, posibilitando la adhesión al Convenio Europeo de Derechos Humanos (Art. I-9).

B) La apuesta por el modelo social europeo consagrado como objetivo de la Unión en desarrollo sostenible basado en una economía social de mercado altamente competitivo, tendente al pleno empleo y al progreso social. Combatir la exclusión social y la discriminación, fomentando la justicia, la protección social, la igualdad entre mujeres y hombres, la solidaridad entre generaciones y la protección de colectivos marginados destacando los derechos de los niños.

C) El interés por la prosecución de la paz no sólo en el ámbito territorial de la Unión, sino también en el resto del mundo para lo cual se prevé un auténtica Europa de la defensa, y reconociendo los espacios de libertad, seguridad y justicia.

En lo que más se progresa es en el andamiaje para una política exterior y de seguridad común, necesidad absoluta a la luz de los acontecimientos de Irak, y anteriormente en la guerra de Kosovo. Europa debe ganar autonomía militar y diplomática respecto a los Estados Unidos; lo que le exige una mayor unidad y solidaridad ante las amenazas bélicas y el terrorismo. Para lograr éxito en estos objetivos cree- 
mos que la figura del Ministro Europeo de Asuntos Exteriores se convierte en un paso algo más que simbólico.

Es preocupante el desplazamiento del poder institucional desde la Comisión Europea al Consejo de Ministros. La Comisión, de momento con 25 miembros que deben defender los intereses de la Unión Europea, es demasiado amplia e intergubernamental, y puede acabar siendo la intendencia del Consejo Europeo. También es de lamentar la erosión sufrida, por su poder de control, sobre el Pacto de Estabilidad que subyace a la Unión Monetaria. No obstante, el paso dado el día 18 de junio es un hito histórico que aún no se ha cerrado; falta la ratificación unánime de todos los países firmantes, bien por referéndum, bien por cada Parlamento nacional, a fin de que su entrada en vigor se efectúe, probablemente, el $1 .^{\circ}$ de noviembre de 2006 . Le queda pues un largo y tortuoso camino hasta que pueda considerarse definitivamente aprobada. Este texto, excesivamente largo, farragoso y complejo, no indica un camino claro para Europa, pero nos proporciona un ropaje jurídico en el que todos los ciudadanos y todos los Estados, al margen de sus dimensiones, deberían encontrar su lugar correspondiente. Así como el Acta Única fue la del Mercado interior y el Tratado de Maastricht el del Euro, el nuevo texto encuentra su hilo conductor en la política exterior y de seguridad común cuyo andamiaje comenzó a montarse antes de que el Tratado Constitucional fuese aprobado.

El Presidente del Gobierno español, J.L. Rodríguez Zapatero, en su comparecencia ante el Congreso de los Diputados (hecho sin precedentes en España), el miércoles 23 de junio, prometió un referéndum en el menor plazo de tiempo posible para aprobar el Tratado Constitucional. La fecha límite para la consulta sería el día 1 de noviembre de 2006. Este será el segundo referéndum consultivo de la democracia española, pues el primero se celebró en 1986 recayendo la consulta sobre la entrada de España en la O.T.A.N. El Tratado aprobado el día 18 de junio en Bruselas encaja perfectamente en la calificación de «Decisión política de especial trascendencia», que según el artículo 92 de la Constitución Española justifica el referéndum consultivo. Nos encontramos ante un texto que, en virtud del principio de primacía, y tal y como se deduce de su contenido - art. 1-6-, en ocasiones se aplicará con preferencia a la propia Constitución nacional, que es la norma suprema según los artículos 9,1 y 53,1. El momento se presenta como especialmente adecuado ante el cambio de modelo europeo, la ampliación, el desarrollo de un corpus político de la Unión Europea que incluye la Carta de Derechos, el impulso de la política exterior, de seguridad y defensa común, más la lucha contra el terrorismo. 
El Presidente del Gobierno también prometió consultar a todas las fuerzas políticas sobre la fecha de celebración del referéndum consultivo y sobre la pregunta a formular, ya que la convocatoria requiere el acuerdo de la Cámara Baja. Finalmente, el día 12 de enero de 2005 se convocó el referéndum consultivo de ratificación en España preguntándole a los españoles: ¿Aprueba usted el Tratado por el que se establece una Constitución para Europa? La fecha fijada para su celebración fue el domingo 20 de febrero. El día 13 de enero, por su parte, el Parlamento Europeo adoptó un dictamen muy favorable al Tratado Constitucional en el que por vez primera se adhiere a la práctica totalidad de sus contenidos. El peligro general para este todavía Proyecto normativo radica en el posible fracaso de la ratificación en alguno de los 25 Estados miembros. Cabe, además, la baja participación en las consultas que le restaría la legitimidad precisa para su implantación.

El órgano llamado a estudiar si el texto europeo contradice el contenido de la Constitución Española es el Consejo de Estado (supremo órgano consultivo del Gobierno, según el artículo 107 de la Constitución). Pues, más allá del deseo de incorporar una referencia general a este texto, como prometió ante el Congreso de los Diputados en su discurso de investidura Rodríguez Zapatero, al hablar de las reformas a acometer en nuestra ley fundamental, la integración europea supone en algunos casos limitaciones a la soberanía del Estado y no sólo traspaso de competencias. La ocasión debía haber sido aprovechada para explicar el Proyecto de Tratado Constitucional a la ciudadanía con una extensa campaña informativa que acerque Europa a los ciudadanos. Hubiera sido deseable también haber aprovechado ese momento, para resolver el encaje de bolillos del Estado de las Autonomías en el marco de una Unión Europea de Estados y de ciudadanos.

En el caso de que se aprecien discordancias entre el Tratado Constitucional y la Constitución Española, la vía jurídica a seguir para resolverlas, está prevista en el artículo 95.2 de nuestra ley de leyes: se trata del recurso previo de inconstitucionalidad frente a Tratados Internacionales. Los entes legitimados para dirigirse al Pleno del Tribunal Constitucional son el Gobierno o cualquiera de las Cámaras, y el procedimiento a seguir está previsto en el artículo 78 de la Ley Orgánica del Tribunal Constitucional; la declaración que al respecto emita el Tribunal Constitucional tiene efectos vinculantes.

La oportunidad de esta competencia del máximo intérprete de la Constitución está fuera de toda discusión; buena prueba de ello fue el requerimiento formulado al Alto Tribunal con motivo de la ratificación del Tratado de Maastricht, y la necesaria reforma de la Constitución (ar- 
tículo 13.2) que de ello se derivó. Esto es así, porque la firma de un Tratado Internacional que contenga estipulaciones contrarias a la Constitución exigirá, a tenor del artículo 95.1 de la Constitución española, la previa revisión constitucional. Solamente a través de la reforma previa a la ratificación del Tratado se salva el carácter de norma suprema de la Constitución; si no se hace esto así, estamos cediendo a la Unión Europea la competencia de reformar la Constitución (Poder Constituyente Constituido), que no se encuentra entre las que el artículo 93 prevé traspasar.

El otro camino a seguir aparece contemplado en el artículo 161.1 de la Constitución en relación con los artículos $2.1, \mathrm{e}$ ) y $27,2, \mathrm{c}$ ) de la Ley Orgánica del Tribunal Constitucional: se trata del recurso directo de inconstitucionalidad frente a Tratados Internacionales. Este procedimiento, a posteriori, cuando el Tratado sea ya norma de obligado cumplimiento en nuestro país garantiza la primacía de la Constitución sobre las disposiciones normativas con rango de ley, y es evidente que las consecuencias jurídicas de este control son mucho más drásticas que las que se desprenden del control previo de constitucionalidad.

\section{EL REFERÉNDUM ESPAÑOL SOBRE EL TRATADO CONSTITUCIONAL (QUE NO CONTRADICE LOS POSTULADOS CONSTITUCIONALES)}

El pueblo español fue el primero en ratificar, vía referéndum, el día 20 de febrero de 2005, el Tratado Constitucional. Previamente lo habían hecho, por vía parlamentaria, Lituania, Hungría y Estonia. Faltan por celebrar los referendos prometidos de Francia (el 29 de mayo de 2005), en julio probablemente Luxemburgo, en otoño Dinamarca y para el 2006, Polonia, Portugal, Irlanda, Reino Unido, República Checa y Bélgica. EI resto de los países utilizarán la vía parlamentaria conforme a lo prescrito en sus respectivas constituciones.

La ciudadanía española, muy europeísta, se ha manifestado de forma clara a favor del Proyecto europeo: El Sí obtuvo el $76.6 \%$ de los votos, frente a un $17.2 \%$ del No, los votos en blanco sumaron el $6 \%$, mereciendo ser resaltado el escaso entusiasmo que nuestros políticos supieron transmitir a los votantes que acudieron a las urnas con una participación en torno al un $42.4 \%$ del censo; la cifra más baja de participación en todas las citas, en el ámbito nacional, con las urnas desde que se restableció la democracia. Los resultados se han prestado a interpretaciones sesgadas desde todos los partidos políticos de ámbito nacional, pero, a nivel de la Unión Europea se han considerado alta- 
mente positivos por el efecto de arrastre que pueden ejercer en los supuestos de los otros nueve países pendientes de celebrar referendos. Pero, la abstención española, que se aproxima al 58\% (en las elecciones al Parlamento Europeo de junio de 2004 ya superó el 54\%), obligará al resto de los gobernantes europeos a realizar un considerable esfuerzo para movilizar a unos electores que hoy por hoy aparecen apáticos o divididos.

A partir de los resultados claramente positivos del referéndum en España quedaba por cumplir lo preceptuado en el artículo 93 de la CE: que una Ley Orgánica de las Cortes Generales autorice la celebración del Tratado Constitucional. Esta había sido la vía común utilizada desde que firmamos el Tratado de Adhesión en 1985. El 28 de abril de 2005 el Congreso de los Diputados ratificó por 311 votos a favor y 19 en contra el Tratado por el que se establece una Constitución para Europa, con lo cual sólo queda la ratificación del Senado que se celebrará próximamente a través del procedimiento en lectura única.

El Consejo de Estado, máximo órgano consultivo del Gobierno (Art. 107 de la CE) había emitido un dictamen, con fecha 21 de octubre de 2004, sobre el Tratado Constitucional en el que efectuó diversas consideraciones acerca de la compatibilidad entre dicha norma y la Constitución Española. El precepto que más dudas le planteaba era el artículo I-6 en virtud del cual: " La Constitución -europea- y el Derecho adoptado por las instituciones de la Unión en el ejercicio de las competencias que se la atribuyen a ésta primarán sobre el Derecho de los Estado miembros». Este pronunciamiento, a juicio del Consejo de Estado, al proclamar con rango normativo la primacía del Derecho comunitario puede contradecir el carácter de Norma Suprema que se proclama de la Constitución Española en varios de sus preceptos (Art. 1.2; 9.1; 53.1; 95.1; 161; 163; 167; 168 y disposición derogatoria, entre otros). Por ello, recomendaba al Gobierno que, con carácter previo a la ratificación, hiciera uso de la facultad prevista en el artículo 95.2 de la CE para requerir al Tribunal Constitucional acerca de la posible contradicción entre la norma internacional y nuestra Norma Suprema. A la luz del contenido de ese informe, el Gobierno acordó, en Consejo de Ministros, el día 5 de noviembre de 2004 consultar al Tribunal Constitucional. El contenido de la consulta vinculante fue pactado por la Vicepresidenta del Gobierno y el líder de la oposición reafirmando la fecha y la pregunta del referéndum. Se aceleraron los trámites a los efectos de que el Alto Tribunal pudiera pronunciarse antes del 20 de febrero de 2005, fecha fijada para el referéndum consultivo. El requerimiento al Tribunal Constitucional planteado, el 5 de noviembre por el Abogado del Estado, en representación del Gobier- 
no de la Nación solicitaba una declaración vinculante sobre los siguientes extremos:

1) La existencia o inexistencia de contradicción entre la $C E$, el Art. I6 del Tratado por el que se establece una Constitución para Europa.

2) A la vista de los establecido en el Art. 10.2 de la CE, la existencia o inexistencia de contradicción entre la Constitución Española y los artículos II-111 y II- 112 del Tratado por el que se establece una Constitución para Europa que forman parte de la Carta de Derechos Fundamentales de la Unión Europea.

3) La suficiencia o no del artículo 93 de la CE a los efectos de la prestación del consentimiento del Estado al Tratado por el que se establece una Constitución para Europa.

4) En su caso, el cauce de reforma constitucional que hubiera de seguirse para adecuar el Texto de la Constitución Española al Tratado por el que se establece una Constitución para Europa.

Con fecha 13 de diciembre de 2004 el Pleno del Tribunal Constitucional pronunció la correspondiente declaración en la cual, por mayoría de 9 votos positivos frente a tres votos disidentes, mantiene que no existe contradicción entre la CE y los artículos I-6, II-111 y II-112 del Tratado firmado en Roma el 29 de octubre de 2004. Así mismo sostiene que el Art. 93 de la CE es suficiente para la prestación del consentimiento del Estado al Tratado en cuestión y que por lo tanto no es preciso entrar a debatir acerca de cual debería ser, en su caso el cauce para la correspondiente reforma constitucional.

Hasta fechas muy próximas al pronunciamiento del supremo intérprete de la Constitución (Art. 1.1 de la LOTC) voces autorizadas en la disciplina constitucional se habían dejado oír en torno a la conveniencia política de la reforma de nuestra Norma Suprema porque la misma era jurídicamente necesaria. Se estaba de acuerdo en el contenido mínimo de la misma (reformar el Art. 93 por la vía del Art. 167 constitucional de fácil logro por su bajo coste político) y se discutía la posibilidad de una reforma al máximo que conllevaba superar un alto riesgo por el difícil procedimiento que debía superar. También se lamentaba la ocasión perdida en la declaración del Alto Tribunal de 1992, con motivo de la firma del Tratado de Maastrich, y era de esperar que en esta "convocatoria» superásemos la "asignatura pendiente». Lamentablemente no ha sido así.

Los efectos "erga omnes" que se desprenden de la declaración apoyada por la mayoría de los miembros del Tribunal Constitucional no 
impiden que los estudiosos del tema podamos opinar sobre la misma y manifestar que, algunos en términos generales compartimos las opiniones expresadas en los votos salvados, porque las consideramos constitucionalmente más acertadas. Sorpresivamente el Alto Tribunal se ha apartado de la doctrina mantenida en la declaración de 1992 y en otras sentencias posteriores, y con unos argumentos jurídicos que llaman la atención por su labilidad, elimina el problema de fondo de un plumazo, confirmando las categorías conceptuales de supremacía y primacía, que sin embargo, en la práctica judicial llegan a confundirse.

Entiende la doctrina mayoritaria que el concepto de supremacía atañe a la norma suprema española mientras que la primacía afecta al campo competencial transferido (vía Art. 93) a la Unión Europea que implica necesariamente un cambio subjetivo en el ejercicio de las mismas incluyendo a partir de ahora, la titularidad de esas competencias que seguirán perteneciendo al ámbito interno que mantiene su soberanía (en un nivel menor).

Por lo tanto reconoce un contenido material a un precepto constitucional -el Art. 93 de la $\mathrm{CE}$ - que en la mente de los constituyentes y en su sentido literal no es más que una norma doblemente instrumental, operando con ello una mutación constitucional. Se mantiene dado ese contenido material del que ahora dispone la precitada norma constitucional-que es título suficiente para transferir competencias al ámbito europeo -entre los que se encuentran la posible disponibilidad de normas constitucionales con base en los principios jurisprudenciales sentados por el Tribunal de Luxemburgo que hasta la fecha se habían mantenido como una relación entre Tribunales de órdenes jurisdiccionales diferentes-. La jurisprudencia constitucional y la doctrina española hemos aceptado sin reticencias que el principio de la primacía del Derecho Europeo sobre el Nacional se aceptaba para las normas de rango infraconstitucional y que dicho principio no habilita para "disponer" de las normas de rango constitucional que es lo que ha mantenido el Tribunal de Luxemburgo en reiterada jurisprudencia y que es lo que subyace en el artículo I-6 y a la Declaración de la Convención sobre este precepto. La disparidad criterios mantenidos por los Tribunales Constitucionales de los Estado miembros, por el Tribunal de Justicia de la Unión sobre este punto han provocado que la cuestión de "quién decide quién decide" haya quedado sin resolver hasta el momento presente (POIARES).

Tomando en su literalidad la declaración de nuestro Tribunal Constitucional aparentemente estamos ante una norma (Art. 93 constitucional) que no necesita ser reformada porque está dotada de un contenido 
material que permite traspasar el ejercicio de competencias constitucionales a una organización supranacional, traspaso que implica a partir de ahora la titularidad y el ejercicio, y que por ello actuando sobre las mismas el Derecho de la Unión prevalecerá sobre la propia Constitución porque así se deduce del Tratado Constitucional y lo permite, al parecer, nuestro Art. 93 de la CE. Pienso, honestamente, que se ha ido más allá de lo posible porque al trasladar la capacidad de disponer sobre nuestra Norma Suprema estamos cediendo el Poder de reforma (Poder Constituyente derivado), aunque sea tácita, a una organización supranacional y ello es algo innato, en virtud del principio democrático que es basilar en el moderno constitucionalismo, del Poder constituyente del pueblo soberano (KRIELE, De VeGA, Rubio LlORENTE...).

Hubiera sido constitucionalmente más correcto proceder a reformar nuestra Constitución como prescribe el Art. 95.1 de la CE para salvar su carácter de Norma Suprema (que como tal no reconoce otro superior), actuando como lo han hecho otros países de nuestro entorno (Francia, Alemania y en fechas más recientes Portugal) y prepararla debidamente para los cambios que se avecinan.

La cláusula de reversión, denunciando el Tratado por el procedimiento previsto al respecto y saliendo de la organización supranacional en la que tan a gusto nos encontramos, es un precio demasiado alto, (como también lo son los procedimientos de control constitucional «a posteriori») a pagar por no querer poner en marcha el referéndum necesario (RUBIO LLORENTE) y conformándonos con soluciones de parcheo por medio de un referéndum consultivo y voluntario que no añade más legitimidad al denunciado y aún no desaparecido déficit democrático de la Unión.

A partir del momento de entrada en vigor del Tratado Constitucional, puesto que la ratificación se hará sin reformar nuestra Constitución "no le arrendamos la ganancia» a los jueces españoles que se van a encontrar con problemas insolubles cuando se vean en la tesitura de aplicar normas de la Unión contrarias a nuestra Constitución y el Alto Tribunal se verá abocado a resolver problemas que podían haberse evitado si el contenido de su declaración de 13 de diciembre de 2004 hubiera sido otro.

Quedamos a la espera de la prometida reforma que va a efectuar el Gobierno del señor Rodríguez Zapatero y que afectará, entre otras cuestiones, al reconocimiento del derecho de la Unión Europea en el marco de nuestra Constitución. Parece ser que se llevará a cabo al final de la Legislatura y que el Consejo de Estado está llamado a informarla. ¿Conseguirá su informe obtener mejores resultados que los logrados 
en el momento presente? Desconocemos los términos en que va a ser planteada y quedamos a la espera confiando en que, para el Estado Español soberano, la construcción de la Europa unida en la diversidad se haga en función de los principios que fundamentan el moderno constitucionalismo y no sobre "las ruinas" de la Constitución Española, la mejor que hemos tenido en la historia de los dos últimos siglos y que devolvió a nuestro país la democracia y la libertad de las que tanto adolecíamos.

\section{BIBLIOGRAFÍA DE REFERENCIA}

Sin ánimo exhaustivo y por orden alfabético citamos la bibliografía que hemos consultado en la elaboración de este trabajo:

Alaez Corral, Benito: "Comentario a la STC alemán de 12 de octubre de 1993", en REDC, n. 45.

AA.VV.: Revista de Occidente, enero 2005, colaboraciones de F. RUBIO Llorente, José María de Areilza Carvajal, Julio Crespo e Íñigo MénDEZ DE VIGO.

Alberti RoviRa (dir.) y RoIg Moles (coord): El Proyecto de Nueva Constitución Europea. Balance de los trabajos de la Convención del futuro de Europa, Tirant Lo Blanch, Valencia, 2004.

ALBERTI ROVIRA, Enoch: "La delimitación de las competencias entre la Unión y los Estados miembros», R.E.P., n. ${ }^{\circ}$ 119, Madrid, 2003.

AlbeRTI, E. y RoIG, E.: "Perspectivas actuales del proceso de integración europea», en Europafutura.org., Fundación Carles Pi i Sunyer, Barcelona, 2002.

Aldecoa luzarraga, Francisco: Una Europa. Su proceso constituyente, 2000-2003, ed. Biblioteca Nueva, Madrid, 2003.

AleXY, Robert: Epílogo a la Teoría de los Derechos Fundamentales, Colegio de Registradores de la Propiedad y Mercantiles de España. Centro de Estudios, Madrid, 2004.

Alonso García y Pérez Tremps, P. (dir.): "Constitución europea, constituciones internas e integración", $C D P$, n. $^{\circ}$ 13, 2001.

Alonso García, Enrique: "La incidencia de la entrada en las Comunidades Europeas en el sistema constitucional de fuentes del Derecho". Ponencia presentada al V Congreso de la Asociación Española de Ciencia Política y Derecho Constitucional. San Sebastián, octubre de 1985. 
Alonso García, R.: «El triple marco de protección de los derechos fundamentales en la Unión Europea», Cuadernos de Derecho Público, n. ${ }^{\circ} 13,2001$.

Alonso García, R.: "La Carta de los derechos fundamentales de la Unión Europea», Gaceta Jurídica de la UE y de la Competencia, n. ${ }^{\circ} 209$, 2000.

Alonso García, Ricardo y Sarmiento Ramírez-Escudero, Daniel: "Los efectos colaterales de la Convención sobre el futuro de Europa en la arquitectura judicial de la Unión: ¿Hacia una jurisdicción auténticamente constitucional europea?", R.E.P., n. ${ }^{\circ}$ 119, Madrid, 2003.

Althusius, J.: La Política metódicamente concebida e ilustrada con ejemplos sagrados y profanos, Madrid, 1990.

Álvarez Conde y Garrido Mayol: Comentarios a la Constitución Europea, tres volúmenes, Tirant lo Blanch, Valencia, 2004.

Aмato, G.: "La Convenzione Europea. Primi approdi e dilemmi aperti», Quaderni Costituzionali, año XXII, n. ${ }^{\circ}$ 3, 2002.

ANdRÉs SÁEnz de SANTA MaríA, P.: «Hacia una Constitución Europea: Comentarios sobre los trabajos de la Convención", Revista General de Derecho Europeo, n. ${ }^{\circ} 1,2003$.

ANDRÉS Y SÁENZ de SANTA MARíA, Paz: "La reforma institucional en el Tratado de Niza", Gaceta jurídica de la UE y de la Competencia, 2001, n. ${ }^{\circ} 211$.

Anzo, A.: "La Costituzione europea come problema", Revista Italiana di Diritto Comparato, 2000.

Areilza Carvajal, J. M.: "La reforma de Niza: ¿Hacia que Unión Europea?", Política Exterior, vol. XV, n. ${ }^{\circ} 79,2001$.

Aristóteles: Política. Traducción de J. Marías y M. Araújo. La Habana, 1968.

Astola Madariaga, Jasone: "Reflexiones en torno al control de constitucionalidad del derecho comunitario", Revista de Derecho Político, n. ${ }^{\circ}$ 53, Madrid, 2002.

AZPITARTE SÁNCHEZ, M.: «El Tribunal Constitucional ante el control del Derecho Comunitario derivado", Civitas, Madrid, 2002.

BACIGALUPO SAGgESE, Mariano: "Una nueva arquitectura judicial para la Unión Europea», R.E.P., n. ${ }^{\circ}$ 119, Madrid, 2003.

Balaguer CALlejón, Francisco: "La constitucionalización de la Unión Europea y la articulación de los ordenamientos europeo y estatal» 
en García Herrera, M. A. (dir.): El constitucionalismo en la crisis del Estado social, Bilbao, 1997.

BALAgueR, F.: "Niveles institucionales y técnicas de reconocimiento de los derechos en Europa", en Tecniche di garanzia dei diritti fondamentali, ed. G. Rolla, Torino, 2001.

BARILE, P.: La Costituzione come norme giuridica, Florencia, 1961.

Barnier y Vittorino: Agencia Europa, n. ${ }^{\circ} 8454$ de 3.5.2003.

BARNIER, M.: L'urgence européenne. Note personnelle, Bruseles 17 octubre 2001. http://europa.eu.int/comm/commisioneus/news/interv_es_htm.

BAstid, Paul: L'idée de Constitution, París, 1985.

BERnhARDT, R.: "La Constitución de la Comunidad" en la obra colectiva Treinta años de Derecho Comunitario, Oficina de Publicaciones Oficiales de las Comunidades Europeas, Luxemburgo, 1984.

Biglino Campos, Paloma: Diccionario de términos comunitarios, Madrid, 1977.

Biglino CAMPOS, P.: "Ciudadanía Europea y legitimidad democrática", $R E E, \mathrm{n} .{ }^{\circ}$ 9, 1995.

Biglino CAmpos, Paloma: "Derechos fundamentales y competencias de la Unión: El argumento de Hamilton", Revista de Derecho Comunitario Europeo, n. ${ }^{\circ}$ 14, enero-abril 2003.

Blanco VAldÉs, Roberto: El valor de la Constitución, Alianza Editorial, Madrid, 1994.

Boввı, Norberto: Contribución a la teoría del Derecho, Valencia, 1980.

BÖCKENFÖRDE, Ernst: «Escritos sobre derechos fundamentales», Nomos Verlagsgessellschaft, Baden-Baden, 1993.

BÖCKENFÖRDE, Ernst: Estudios sobre el Estado de Derecho y la democracia, Ed. Trotta, Madrid, 2000.

Bodin, Jean: Les Six Livres de la République, Ed. Aguilar, Madrid, 1961.

BorgeAud, Ch.: Établissement et revision des Constitutions en Amérique et en Europe, París, 1893.

Bourlanges, Jean-Louis: Agencia Europa, n. ${ }^{\circ} 8502$ de 11.7.2003

BRYCE, James: "constituciones flexibles y constituciones rígidas», CEC, Madrid, 1988. 
BURKE, E.: Reflexiones sobre la revolución francesa, Madrid, 1978.

CARnero GonzÁlez, Carlos y otros: La Constitución Europea, Editorial Espejo de Tinta, Madrid, 2005.

Carre de Malberg, R.: "Teoría general del Estado", Fondo de Cultura Económica, México, 1948.

Carrera Hernández, F. J.: "Simplificación de los instrumentos jurídicos en el Tratado Constitucional», Revista de Derecho Comunitario Europeo, n. ${ }^{\circ} 16,2003$.

Carreras SerRa, Francesc: «Análisis del Tratado de Constitución Europea" RFDUC, n. ${ }^{\circ}$ 18, Madrid, 1994.

CarRillo Salcedo, J. A.: «El futuro de la Unión Europea. Algunas reflexiones sobre el papel de Europa en el mundo contemporáneo a la luz de la Declaración de Laeken", Revista de Occidente, febrero 2002.

Carrillo Salcedo, J. A.: «El mecanismo de protección jurisdiccional de los derechos reconocidos en el Convenio Europeo de Derechos Humanos: ¿Ha fracasado el Protocolo de Enmienda n. ${ }^{\circ} 11$ ?", Revista Española de Derecho Europeo, vol. 4, 2002.

Carrillo Salcedo, J. A.: «Notas sobre el significado político y jurídico de la Carta de los Derechos Fundamentales de la Unión Europea», Revista de Derecho Comunitario Europeo, vol. 9, 2001.

Cebada Romero, Alicia: "La naturaleza jurídica de la Unión Europea: Una contribución al debate sobre su personalidad jurídica a la luz de los trabajos de la Convención sobre el futuro de Europa", Revista de Derecho Comunitario Europeo, n. ${ }^{\circ}$ 14, enero-abril 2003.

Chalmers, D.: "Judicial Preferentes and the Comunita Legal Order», 60 $M L R, 1997,164-180$.

CheVallieR, R. M.: «Methode and Reasonings of the European Court in its Interpretation of Community Law", Common Market Law Review, 1964-65.

Chueca SAnCho, A.: Los derechos fundamentales en la Comunidad Europea, Bosch, Barcelona, 1999.

Closa Montero, Carlos: "El Libro Blanco sobre la gobernanza», R.E.P., n. ${ }^{\circ}$ 119, Madrid, 2003.

Closa Montero, y Fernández Sola: La Constitución de la Unión Europea, Centro de Estudios Políticos y Constitucionales, Madrid, 2005. 
Constant, Benjamín: Escritos políticos, Madrid, 1989.

CONSTANTINESCO, V.: "¿Hacia la emergencia de un derecho constitucional europeo?", Cuadernos constitucionales de la Cátedra "Fadrique Furió Ceriol", n. ㅇ 8, Valencia, 1994.

Corcuera AtIenZA, J.: La protección de los derechos fundamentales en la Unión Europea, Dykinson, Madrid, 2002.

CORTÉs MARTín, J. M.: "Afectación individual (230.4 CE): ¿Un obstáculo infranqueable para la admisibilidad del recurso de anulación de los particulares?, Revista de Derecho Comunitario Europeo, n. ${ }^{\circ}$ 16, 2003.

Crossman, R. H. S.: Biografía del Estado Moderno, México, 1982.

CRUZ VILAÇA, J. L. da: "L'evolution du systéme juridictionnel communautaire avant et après Maastricht» en AA.VV: «Festschrift für Ulrich Everling" Nomos Verlagsgesellchaft, Baden-Baden, 1995, Vol I.

CRUz ViLlalón, P.: La formación del sistema europeo de control de la constitucionalidad (1918-1939), Madrid, CEC, 1987.

Cruz VILlalón, Pedro: La Constitución inédita. Estudios ante la constitucionalización de Europa, Editorial Trotta, Madrid, 2004.

De Housse, R.: "Nacimiento de un constitucionalismo transnacional», Foro Internacional, n. ${ }^{\circ}$ 2, abril-junio 2002.

De Miguel Barcena, Josu: "El Consejo de la Unión Europea como foro intergubernamental de la toma de decisiones", Revista de Derecho Político, n. ${ }^{\circ}$ 53, Madrid, 2003.

De Vega García, Pedro: "Constitución y democracia», en "La Constitución de la monarquía parlamentaria», López Pina, Antonio (ed.) FCE, Madrid, 1983.

De Vega García, Pedro: «En torno al concepto político de Constitución», en García Herrera, M. A. (dir.): El constitucionalismo en la crisis del Estado social, Bilbao, 1997.

De Vega García, Pedro: "Jurisdicción constitucional y crisis de la Constitución", R.E.P., n. ${ }^{\circ}$ 7, 1979.

De Vega GaRCía, Pedro: La reforma constitucional y la problemática del poder constituyente, Tecnos, Madrid, 1985.

De Vega García, Pedro: «Mundialización y Derecho Constitucional: la crisis del principio democrático en el constitucionalismo actual», en Revista de Estudios Políticos, n. ${ }^{\circ} 100$, Madrid, 1998 
DeHANE, WeIZSÄCHER y SIMON: "Las implicaciones institucionales de la ampliación, 18.10.1999", en Revista de Derecho Comunitario Europeo, n. ${ }^{\circ}$ 6, julio-diciembre de 1999; Comunicación de la Comisión al Consejo, al PE, al CES y al CDR: "Adaptar las instituciones para que la ampliación sea un éxito", Bruselas, 2.12.1999.Dictamen preceptivo de la Comisión: "Adaptar las instituciones para que la ampliación sea un éxito", COM (2000) B4, en Revista de Derecho Comunitario Europeo, enero-junio de 2000.

Delage, F. y VAlCÁRCEL, D.: «Europa y su Constitución. Valores, interés y estrategias", Política exterior, n. ${ }^{\circ}$ 96, 2003.

Díaz Revorio, F. J.: La Constitución como orden abierto, McGraw Hill, Madrid, 1977.

DíEz de Velasco, M.: El Tribunal de Justicia de las Comunidades Europeas, Madrid, 1984.

DíEZ-HOCHLEITNER, J.: «El futuro sistema competencial comunitario: algunas propuestas de reforma" en García de Enterría, E. (dir.): La encrucijada constitucional de la UE, Civitas, Madrid, 2002.

DíEZ-PICAZO JIMÉnEZ, L. M: "Tratados y Constitución», en Constitucionalismo de la Unión Europea, Madrid, 2002.

DíEZ-PICAZO JIMÉNEZ, Luis María: «Reflexiones sobre la idea de Constitución Europea», Revista de Instituciones Europeas, 1993-2.

Díez-Picazo Jiménez, L. M.: "Constitucionalismo de la Unión Europea», Cuadernos Civitas, Madrid, 2002.

DonAIRE VILLA, F. J.: "El Tratado de Ámsterdam y la Constitución», en REDC, n. ${ }^{\circ}$ 54, Madrid, 1998.

Escóbar Hernández, C.: "Comunidad Europea y Convenio Europeo de Derechos Humanos: ¿El fin de una vieja polémica?», RIE, 1996, n. ${ }^{\circ} 3$.

EVERLING, U.: «Richterliche Rechsforbildung in der Europäische Gemeinschaft», en Juristen Zeitung 5/2000, 3 de marzo.

FernÁNDEZ Esteban, M. ${ }^{a}$ Luisa: "La noción de Constitución europea en la jurisprudencia del Tribunal de Justicia de las Comunidades Europeas", REDC, n. ${ }^{\circ}$ 40, Madrid, 1994.

FERnÁNDEZ SolA, N.: "La subjetividad internacional de la Unión Europea", Revista de Derecho Comunitario Europeo, n. ${ }^{\circ}$ 11, 2002.

FERNÁNDEZ SOLA, Natividad: "La política exterior y la proyección externa de la Unión Europea», R.E.P., n. ${ }^{\circ}$ 119, Madrid, 2003. 
Ferrero, G.: El poder. Los genios invisibles de la ciudad (trad. De Eloy García), 2. ${ }^{a}$ edición, Madrid, 1998.

Figueruelo BurriezA, Ángela: "Acotaciones al tema de las relaciones entre el derecho comunitario y el derecho interno", R.E.P., n. ${ }^{\circ} 45$, Madrid, 1985.

Figueruelo BurriezA, Ángela: "Cuestión prejudicial (art. 177 del TCEE) y recurso de amparo", Revista de la Facultad de Derecho de la Universidad Complutense, n. ${ }^{\circ}$ 18, Madrid, 1994.

Figueruelo BurriezA, Ángela: "La Carta de los Derechos Fundamentales de la Unión Europea y la función de los operadores públicos", Letras Jurídicas, n. ${ }^{\circ}$ 5, 2002.

Figueruelo BurRiezA, Ángela: "La protección de los Derechos Fundamentales en el marco de la Unión Europea", Anuario de la Facultad de Derecho de la Universidad de La Coruña, n. ${ }^{\circ}$ 5, 2001.

FIovarANTI, Mauricio: Constitución, Trotta, Madrid, 2001.

FiovarantI, Mauricio: Los derechos fundamentales. Apuntes de historia de las Constituciones, Trotta, Madrid, 3. ${ }^{\text {a edición, } 2000 .}$

Freixes SANJUÁN, T.: «El Tribunal Europeo de Derechos Humanos y las libertades de la Comunicación", Revista de Derecho Comunitario Europeo, n. ${ }^{\circ}$ 15, año 7, Madrid, 2003.

Freixes, T. y Remotti, J. C.: El futuro de Europa. Constitución y Derechos Fundamentales, Valencia, 2002.

FRIEDRICH, C. J.: Europa: el surgimiento de una nación, Madrid, 1969.

FriedRICH, C. J.: Gobierno Constitucional y democracia, Madrid, 1975.

García de Enterría, E.: "El Tratado de Constitución Europea», REDC, n. ${ }^{\circ}$ 45, Madrid, 1995.

García de Enterría, E.: La Constitución como norma y el Tribunal Constitucional, Civitas, Madrid, 1981.

García de Enterría, E.: La lengua de los derechos. La formación del Derecho Público Europeo tras la Revolución Francesa, Civitas, Madrid, 2001.

García Gestoso, N.: "Algunas cuestiones sobre la soberanía en el proceso de integración europea", R.A.P., n. ${ }^{\circ}$ 57, UNED, Madrid, 2003.

García Gestoso, N.: «El problema de la soberanía en la Unión Europea», Anuario de la Facultad de Derecho de Ourense. Universidad de Vigo, 2002. 
García Gestoso, N.: «El proceso de revisión en el Tratado del Tratado por el que se instituye una Constitución para Europa». Comunicación presentada al VII Congreso Iberoamericano de Derecho Constitucional. Sevilla 3-5 diciembre de 2003.

García Gestoso, N.: "Naturaleza "sui generis" de la Unión Europea: ¿un nuevo concepto de Confederación contemporánea?", CIVITAS EUROPA, n. ${ }^{\circ}$ 9, septiembre 2002.

García Gestoso, N: "La reforma del vínculo asociativo en las formas históricas del Federalismo. Su aplicación a la Unión Europea", Anuario de la Facultad de Derecho de Ourense. Universidad de Vigo, 2003

García Herrera, M. A. (dir): El constitucionalismo en la crisis del Estado social, U.P. Vasco, Bilbao, 1997.

García Pelayo, M.: Derecho Constitucional comparado, Madrid, 1991.

García Pelayo, M.: Las transformaciones del Estado contemporáneo, Madrid, 1991.

GARCía RocA, Javier: "Originario y derivado en el contenido de la Carta de los Derechos Fundamentales de la Unión Europea: los test de constitucionalidad y convencionalidad", R.E.P., n. ${ }^{\circ} 119$, Madrid, 2003.

GeRBER, V.: Über öffentliche Rechte, Tubinga (reimpresión de la edición de 1852).

GISCARD D'ESTAIGN, V.: "Las últimas noticias sobre la Convención europea», El País, 22 de julio de 2002.

GómEZ GUTIÉRREZ y LEÑERo (coord.): Una Constitución para la ciudadanía de Europa: Estudio sobre al Tratado por el que se instituye una Constitución para Europa, Thomson, Aranzadi, Navarra, 2004.

Granado HiJelmo, I.: "La Constitución europea como problema jurídico", RFDUC, n. ${ }^{\circ}$ 18, Madrid, 1994.

Grimm, D: “¿Necesita Europa una Constitución?», Debats, n. ${ }^{\circ}$ 55, marzo 1996.

GutiéRREZ EsPADA, C.: "Reforma de las instituciones en el Tratado Constitucional presentado por la Convención (2003)", Revista de Derecho Comunitario Europeo, n. ${ }^{\circ}$ 16, 2003.

GutiÉRREZ ESPADA, C.: "Una reforma difícil pero productiva: la revisión institucional en el Tratado de Niza", Revista de Derecho Comunitario Europeo, 2001. 
GutiÉRREZ GutiÉRREZ, I.: "Un orden jurídico para Alemania y Europa», Teoría y Realidad Constitucional, n. ${ }^{\circ}$ 3, Madrid, 1999.

HÄBERLE, P.: El Estado Constitucional, UNAM, México, 2001

HÄBERLE, Peter: Retos actuales del Estado Constitucional, IVAP, Oñate, 1996.

HABERMAS, J.: "¿Por qué Europa necesita una Constitución?», New Left Review, n. ${ }^{\circ} 11,2001$.

HABERMAS, Jürgen: La constelación posnacional, Paidós Ibérica S.A., Barcelona, 2000.

Hamilton, A.; MAdison, J.; JAY, J.: El Federalista, México, 1982.

HeLleR, Hermann: La soberanía. Contribución a la teoría del derecho estatal y del derecho internacional, UNAM, 1965

Heller, Hermann: Teoría del Estado, Fondo de Cultura Económica, México D.F., 1985.

Herrero de la Fuente (ed.): "La Carta de los derechos fundamentales de la Unión Europea. Una perspectiva plurisdisciplinar», Cuadernos del Instituto Rei Alfonso Henriques de Cooperación Transfronteriza, n. ${ }^{\circ}$ 2, Zamora, 2003.

HeSSE, Konrad: Escritos de Derecho Constitucional, CEC, Madrid, 1983.

HeSSE, Konrad: Escritos de Derecho Constitucional, CEC, Madrid, 1992.

HUBER, P. M.: «Europäisches und nacionales Verfassungsrechts» en las actas de la Vereinung der Deutschen Staatsrechtslehrer, 2001.

IPSEN, H. P.: «Die Bundesrepublik Deutschland in den Europaischen Gemeinchaften" en ISENSEE-KIRCHHOF (ed.): Handbuch des Staatsrechts, Heidelberg, 1992.

ISNARD: Archives Parlamentaires, vol. LXIV.

JANER TORRENS, J. D.: «El papel de los particulares en la constatación de conductas contrarias al DC", GJ de la Unión Europea y de la Competencia, n. ${ }^{\circ} 214,2001$.

JelLineK, G.: Reforma y mutación de la Constitución, C.E.C., Madrid, 1991.

JeLlineK, G.: Teoría general del Estado, Buenos Aires,1978.

JELLINEK, G.: Teoría general del Estado, Madrid, 1915.

Jennings, I.: The Law and the Constitution, Londres, 1938. 
JIMÉNEZ CAMPO, Javier: "Algunos problemas de interpretación en torno al Título X de la Constitución", en Revista de Derecho Político, n. ${ }^{\circ}$, Madrid, 1980.

KANT, I.: La paz perpetua, Madrid, 1985.

KELSEN, Hans: Esencia y valor de la democracia, 2. ${ }^{a}$ ed. Guadarrama, Barcelona, 1977.

KELSEN, Hans: Teoría pura del derecho, Editorial Universitaria de Buenos Aires, 1991.

KRIELE, Martín: Introducción a la teoría del Estado. Fundamentos históricos de la legitimidad del Estado Constitucional Democrático, Depalma, Buenos Aires, 1980.

La Pergola, A.: Los nuevos senderos del federalismo, Madrid, 1994.

Laband, P.: Le Droit Public de l'Empire Allemand, París, 1900.

LAMASSOURE: A5-0133/2002, PE 304.276.

LASAgabaster HerRarte, Iñaki: "Las Comunidades Europeas y los derechos fundamentales", REDC, n. ${ }^{\circ}$ 18, Madrid, 1986.

LASo PÉREZ, J. J.: «El Tratado de Ámsterdam y el respeto de la democracia y los derechos humanos", Boletín Europeo de la Universidad de La Rioja, n. ${ }^{\circ}$ 2, 1998.

LASSAlle, Ferdinand: ¿Qué es una Constitución?, Barcelona, 1984.

LAVILLA ALSINA, L.: "Las relaciones entre los ordenamientos nacional y comunitario", en La Constitución española en el ordenamiento comunitario europeo. XVI Jornadas de Estudio organizadas por la DGSJE, vol I., Madrid, 1995.

LEIBHOLZ: «Die Verfassungsdurchbrechung», en Arch. des off. Rechts, Tubinga, 1932.

LENAERTS, K.: "Constitutionalism and the many faces of Federalism", American Journal of Comparative Law, 38, 1990.

LIÑÁn Nogueras, Diego: «De la ciudadanía Europea a la ciudadanía de la Unión", Gaceta Jurídica de la CE, 1992, D17.

Loewenstein, Karl: Teoría de la Constitución, Ed. Ariel, Barcelona, 1982.

LÓPEZ AgUILAR, Juan Fernando: "Una idea constitucional de la Europa de los ciudadanos", R.E.P., n. ${ }^{\circ} 119$, Madrid, 2003 
LÓPEZ BASAguREN, Alberto: “¿Réquiem por la Constitución? El ordenamiento constitucional en la integración comunitaria", en Civitas Europa, $\mathrm{n} .{ }^{\circ} 2,1999$.

LóPez CASTILlo, A.: "Algunas consideraciones sumarias en torno a la Carta de Derechos Fundamentales de la UE», R.E.P., 2001.

López Castillo, A.: Constitución e integración, Madrid, 1997.

LÓPEZ CASTILlo, A.: "La jurisprudencia iuscomunitaria del Tribunal Constitucional a doce años de la integración española en las Comunidades Europeas» en P., n. ${ }^{\circ} 99$ (1998).

López Castillo, Sálz Arnaíz, Ferreres Comella: Constitución Española y Constitución Europea. Análisis de la declaración del Tribunal Constitucional 1/2004, de 13 de diciembre, Dykinson, Madrid, 2005.

López GARRIDO, Diego: La Constitución Europea, Editorial Bomarzo, Albacete, 2005.

LóPEZ PINA, A.: "La ciudadanía, presupuesto de una República Europea (Apuntes para una política del Derecho)", Civitas Europa, n. ${ }^{\circ} 4$, marzo 2000.

LÓPEZ PINA, Antonio: Europa un proyecto irrenunciable, Dykinson, Madrid, 2004.

López-PinA, A. y GutiérRez GutiérRez, l.: Elementos de Derecho Público, Marcial Pons, Ediciones Jurídicas y Sociales S.A., Madrid, 2002.

LóPEZ-PInA, A. y GutiérRez GutiéRREZ, I.: «Preservación de la Constitución, reforma de los Tratados", Civitas Europa, n. ${ }^{\circ}$. Septiembre 2001.

LouIS, J. V.: L'ordre juridique communautaire, 6. ${ }^{\text {a }}$ ed. Luxemburgo, 1998.

LouIs, J. V.: "La Convención ¿en camino hacia el éxito?», Eurobask, n. ${ }^{\circ}$ 7, mayo 2003.

Lucas Verdú, Pablo: Curso de Derecho Político, vol II, Tecnos, Madrid, 1986.

LUCAS Verdú, Pablo: La Constitución abierta y sus enemigos, Ed. Beramar, S.A., Madrid, 1993.

Maestro Buelga, G.: "Globalización y Constitución débil», Teoría y Realidad Constitucional, n. ${ }^{\circ}$ 7, Madrid, 2001.

MAESTRO, Gonzalo: “Globalización y constitución débil», en Teoría y realidad constitucional, n. ${ }^{\circ}$ 7, 2001.

MAISTRE, J. De: Consideraciones sobre Francia, Madrid, 1990 
MANCINI G.. Federico versus WeILER, J. H. H.: «Europe-The Case for Statehood... and the Case Against An Exchange" en Internet: http://www.jeanmonnetprogram.org/papers/papers98.html.

MANGAs MARTín, Araceli y LIÑÁn Nogueras, Diego: Instituciones y derecho de la Unión Europea, Ed. Tecnos, Madrid, 2002.

MANGAs MARTín, Araceli: Derecho comunitario europeo y derecho español, 2. ${ }^{a}$ ed., Madrid, 1987.

MANGAs MARTín, Araceli: "La ciudadanía de la Unión», en AA.VV: El Defensor del Pueblo en el Tratado de la Unión Europea, Universidad Carlos III, Madrid, 1993.

MAngas Martín, Araceli: La Constitución Europea, lustel, Biblioteca Jurídica Básica, Madrid, 2005.

MAngas MARTín, Araceli: "La dinámica de las revisiones de los Tratados y los déficit estructurales de la Unión Europea: Reflexiones generales críticas", en el Libro homenajee al Profesor M. Diez de Velasco, Ed. Tecnos, Madrid, 1993.

MANGAS MARTín, Araceli: "La Unión Europea y su futuro: El debate competencial», Noticias de la Unión Europea, n. ${ }^{\circ}$ 218, marzo de 2003.

MANGAS MARTín, Araceli: "Reflexiones en torno al "proceso de constitucionalización" de la integración europea", en Mariño Fernández, F. (ed.): El Derecho Internacional en los albores del siglo XXI. Homenaje al profesor Juan Manuel Castro-Rial Canosa, Ed. Trotta, Madrid, 2003.

MANgas Martín, Araceli: "Reflexiones sobre el Tratado de Constitución Europea ante la perspectiva de la reforma de $1996 ", R E D C, \mathrm{n} .{ }^{\circ} 45$, 1995.

Maquiavelo, Nicolás: El príncipe, Madrid, 1988.

MARIÑo MenÉndeZ, F. (ed.): «El Derecho Internacional en los albores del siglo XXI", Homenaje al Prof. Juan Manuel Castro-Rial Canosa. Ed. Trotta, Madrid, 2003.

MARISCAL, N.: Teorías políticas de la integración europea, Tecnos, Madrid, 2003.

MARTIN NetTesheim: «El proceso de constitucionalización: consideraciones prácticas para la Conferencia gubernamental de 2004", R.E.P., n. ${ }^{\circ}$ 119, Madrid, 2003.

MARTín y PÉREZ de NANCLARES, J.: El federalismo supranacional: ¿Un nuevo modelo para la Unión Europea?, Consejo Vasco del Movimiento Federal Europeo, Vitoria, 2003. 
Martín y Pérez de Nanclares, José: “¿Necesita la Unión Europea una Constitución?. Reflexiones en torno a una discusión estéril», Boletín Europeo de la Universidad de La Rioja, n. ${ }^{\circ}$ 0, 1997.

Martín y Pérez de NANClares, José: El sistema de competencias de la Comunidad Europea, McGraw Hill, Madrid, 1997.

Martín y PÉrez de NANCLARES, José: «El Tratado de Constitución Europea: reflexiones sobre los trabajos de la Convención", Revista de Derecho Comunitario Europeo, n. ${ }^{\circ}$ 15, Madrid, 2003.

Martín y Pérez de NANClARES, José: "La Constitución de la UE: Reflexiones acerca del debate constitucional pendiente", en El futuro de la Unión Europea, OREJA AguiRre (director).

MARTín y PÉREZ de NANCLARES, José: "La reforma de Niza: compleja, insuficiente, provisional e incierta", Boletín Europeo de la Universidad de La Rioja, n. ${ }^{\circ}$ 7-8, 2001.

Martínez SieRra, J. M.: "El debate constitucional europeo» en Revista de Estudios Políticos, n. ${ }^{\circ}$ 113, 2001.

MASSIMO CORIO: "Aspectos militares de la gestión de crisis en el marco de la PESD", R.E.P., n. ${ }^{\circ}$ 119, Madrid, 2003.

Matia Portilla, F. J.: La protección de los Derechos Fundamentales en la Unión Europea, Civitas, 2002.

Matia Portilla, Francisco Javier: «Parlamento Europeo y Parlamentos nacionales: doble legitimidad en el marco de la Unión Europea", R.E.P., n. ${ }^{\circ}$ 119, Madrid, 2003.

Mclıwain, C. H.: Constitucionalismo antiguo y moderno, Madrid, 1991.

MclLwaIN, Charles Howard: "Some llustration for the Influence of unchanged. Names for changing Institutions", en Interpretations of Modern Legal Philosophies: Papers Presented to Roscoe Pound (New York, 1947).

MedinA, Manuel: Hacia una Constitución Europea, Valladolid, 1995.

MILLÁN Moro, L.: «Aplicabilidad directa y efecto directo en Derecho comunitario según la jurisprudencia del Tribunal de justicia», RIE, Madrid, 1984.

MonACO, R.: «Rapporti tra diritto comunitario e diritto interno», en el Primer Volumen del "Manuale di dirito comunitario», en colaboración con E. Pennacchini y otros. UTET, Torino, 1983. 
MoRI, Paola: «Derecho comunitario y Derecho interno en una sentencia reciente del Tribunal Constitucional italiano", en $R I E$, vol. 12., n. ${ }^{\circ} 3$, Madrid, 1985.

Morodo LeOncio, Raúl: "Constitución, legalidad y legitimidad", Boletín Informativo del Seminario de Derecho Político de la Universidad de Salamanca, n. ${ }^{\circ} 26,1963$.

MorTATI, Constantino: "La Constitución en sentido material», CE Políticos y Constitucionales, Madrid, 2000.

Muñoz Machado, Santiago: El ordenamiento jurídico de la Comunidad Europea y la Constitución Española, Civitas, Madrid, 1980.

Olesti RAYo, A.: "Las modificaciones institucionales en el Tratado de Niza", Boletín Europeo de la U. de La Rioja, n,o 718, 2001.

OLIVER LEÓN, Baldomero: "La Carta de los derechos fundamentales de la Unión Europea en el debate constitucional europeo", R.E.P., n. ${ }^{\circ} 119$, Madrid, 2003.

ORdoñez Solís, David: «El espacio judicial de libertad, seguridad y justicia en la Unión Europea", R.E.P., n. ${ }^{\circ}$ 119, Madrid, 2003.

Oreja Aguirre, Marcelino: El futuro de la Unión Europea. Unión política y coordinación económica, Ed. Dykinson, Madrid, 2002.

Oreja AguirRe, Marcelino: "En busca de una Constitución para Europa», Política Exterior, n. ${ }^{\circ}$ 88, Madrid, 2002.

PACE, A.: «¿Para qué sirve la Carta de los Derechos Fundamentales de la Unión Europea? Notas preliminares", Teoría y Realidad Constitucional, n. ${ }^{\circ}$ 6, Madrid, 2000.

PACHE, E.: «Eine Verfassung für Europa. Krönungoder Kollaps der europäischen Integration?" Europarecht, 2002.

PALACIO, Ana: "La Convención Europea, un gran avance», Política Exterior, n. ${ }^{\circ}$ 91, 2003.

Pereira Menaud, Antonio Carlos: “ Invitación al estudio de la Constitución de la Unión Europea", Revista de Derecho Político, n. ${ }^{\circ}$ 53, Madrid, 2002.

Pérez BernáRdez, C: Las relaciones de la Unión Europea con organizaciones internacionales: Análisis jurídico de la práctica internacional, Comunidad de Madrid, Consejería de Educación, Madrid, 2003.

Pérez Calvo, A.: "Derecho Comunitario, Derecho interno y principio de competencia», Comunicación presentada al VII Congreso Iberoa- 
mericano de Derecho Constitucional. Sevilla, 3-5 de diciembre de 2003.

Pérez Calvo, A.: «Integración Europea y Constitución Europea», Civitas Europa, n. ${ }^{\circ}$, marzo 2000.

Pérez Calvo, A.: "La dimensión comunitaria del Estado en la Europa Occidental», Civitas Europa, n. ${ }^{\circ} 1,1998$.

Pérez CAlvo, A.: "La nueva dimensión comunitaria del Estado moderno" en García HeRrera (dir.): El constitucionalismo en la crisis del Estado social, Bilbao, 1997.

Pérez Calvo, A.: "Las transformaciones estructurales del Estado-Nación en la Europa Comunitaria», REP, n. ${ }^{\circ}$ 99, 1998.

Pérez Calvo,, Alberto: Estado autonómico y Comunidad Europea, Madrid, 1994.

Pérez LuÑo, A. E.: Los derechos fundamentales, Tecnos, Madrid, 1986.

Pérez Royo, Javier: Curso de Derecho Constitucional, Ed. Pons, Madrid, 2003.

Pérez Royo, Javier: La reforma de la Constitución, Congreso de los Diputados, Madrid, 1987.

PÉREZ Royo, Javier: Las fuentes del Derecho, Tecnos, Madrid, 4. ${ }^{a}$ Edición, 1994.

Pérez Serrano, N.: Tratado de Derecho Político, Madrid, 1984.

Pérez Serrano, Nicolás: Escritos de Derecho Político, Madrid, 1984.

PÉREZ TREMPS, P.: «Justicia comunitaria, justicia constitucional y Tribunales ordinarios frente al Derecho Comunitario", en REDC, n. ${ }^{\circ} 13$, Madrid, 1985.

Pérez Tremps, P: "La Constitución española antes y después de Niza», Cuadernos de Derecho Público, n. . 13, 2001.

Pérez Tremps, Pablo: Constitución Española y Comunidad Europea, Civitas, 1994.

Pérez TRemps, Pablo: Constitución Española y Comunidad Europea, Madrid, 1994.

PéRez VerA, Elisa: "La Carta de los Derechos Fundamentales de la Unión Europea", en AA.VV.: Los Derechos Humanos. Libro Homenaje al Excmo. Sr. D. Luis Portero García, Universidad de Granada, 2001. 
PÉREZ VerA, Elisa: «El Tratado de la Unión Europea y los derechos humanos", RIE, n. ${ }^{\circ} 2,1993$.

Pescatore, P.: Le droit de l'intégration, Leiden, 1972.

Pescatore, P.: "Aspectos judiciales del acervo comunitario", en RIE, Madrid, 1981.

Pi y LLORENS, M.: Los derechos fundamentales en el ordenamiento comunitario, Ariel Derecho, Barcelona, 1999.

PLATÓN: "Las leyes o de la legislación», en Obras Completas, Madrid, 1966.

Plender, R. y Pérez SAntos, J.: Introducción al Derecho Comunitario Europeo, Civitas, Madrid, 1984.

Poiares Maduro, Miguel: "Las formas del poder constitucional de la Unión Europea», R.E.P,. n. ${ }^{\circ}$ 119, Madrid, 2003.

Pons Rafols, X.: "La Unión Europea ante la Corte Penal Internacional», Revista de Derecho Comunitario Europeo, n. ${ }^{\circ}$ 16, 2003.

POWELL, Ch: «El Tratado español ante el Tratado Constitucional», Real Instituto Elcano de Estudios Internacionales y Estratégicos. www.realinstitutoelcano.org/analisis/310.asp.

Quemonne, J. L.: "L'Union européenne entre "gouvernance" et "gouvernement" ou quelle Constitutión pour une Fédération d'États-nations ?", Revue du Droit Public, 1-2, 2002.

QuermonNE, J. L.: "La question du gouvernement européen», Notre Europe, Études et Recherches, n. ${ }^{\circ}$ 20, nov. 2002.

RAmiro Rıco, Nicolás: El animal ladino y otros estudios políticos, Madrid, 1980.

Rasmussen, H.: La Constitución de la Comunidad Económica Europea, trad. de A. Escribano Fernández, Trivium, Madrid, 1990.

REICH, C.: "Qu'est-ce que... le déficit democratique ?", Revue du marché Commun, 1991.

Remiro Brotons, A.: La acción exterior del Estado, Tecnos, Madrid, 1984.

RIFKIN, Jeremy: El sueño europeo: Cómo la visión europea del futuro está eclipsando el sueño americano, Ediciones Paidós. Barcelona, 2004.

Rodríguez BereiJo, A.: "La Carta de los derechos fundamentales de la Unión Europea», Gaceta Jurídica de la Unión Europea y de la Competencia, 2000. 
RODRíGueZ DíAZ, Ángel: "Sobre la naturaleza jurídica de la Carta de los Derechos Fundamentales de la Unión Europea", Revista de Derecho Político, n. ${ }^{\circ}$ 51, Madrid, 2001.

Rodríguez Iglesias, G. C. y LiÑÁn Nogueras, D. J.: El Derecho Comunitario Europeo y su aplicación judicial, Madrid, 1993.

Rodríguez Iglesias, G. C. y Valle Gálvez, A.: «El Derecho Comunitario y las relaciones entre el Tribunal de Justicia de las Comunidades Europeas, el Tribunal Europeo de Derechos Humanos y los Tribunales Constitucionales nacionales", Revista de Derecho Comunitario Europeo, n. ${ }^{\circ} 2,1997$.

Rodríguez IgLESIAS, G. C.: "Efectos internos del Derecho Comunitario», en Documentación Administrativa, n. ${ }^{\circ}$ 201, Madrid, 1984.

Rodríguez IgLESIAS, G. C.: "La constitucionalización de la UE», Revista de Derecho Comunitario Europeo, n. ${ }^{\circ}$ 16, 2003.

Rodríguez IgLesias, G. C.: «Problemas jurídicos de la adhesión de España a la Comunidad Europea", en la obra colectiva Problemas jurídicos de la adhesión de España a la CEE, U.P.V. San Sebastián, 1984.

RODRÍGUEZ IGLESIAS, G. C.: «Problemas jurídicos de la adhesión española a la Comunidad Europea", en AA.VV.: Cursos de Derecho Internacional de Vitoria Gasteiz, 1984, Oñate, 1985.

RODRígueZ IgLESIAS, G. C.: "Consideraciones sobre la formación de un Derecho Europeo", Gaceta Jurídica de la UE y de la Competencia, 1999, n. 200.

Rodríguez Iglesias, G. C.: "Tribunales Constitucionales y Derecho Comunitario", en AA.VV.: Hacia un nuevo orden internacional y Europeo. Homenaje al Profesor M. DíEZ DE VELASCO, Madrid, 1993.

RODRÍGUEZ, Ángel: Integración europea y derechos fundamentales, Civitas, Madrid, 2001.

Rodríguez-ZAPATA y PÉREZ, J.: "Derecho internacional y sistema de fuentes del Derecho: La Constitución Española», en la obra colectiva $\mathrm{La}$ Constitución Española y las fuentes del Derecho, vol. III. I.E.F., Madrid, 1979.

Rodríguez-Zapata y Pérez, J.: Constitución, Tratados internacionales y sistema de fuentes del Derecho, Bolonia, 1976.

RodrígueZ-ZAPATA y PÉREZ, Jorge: "Los Tratados Internacionales y los controles de constitucionalidad", vol. III de la obra colectiva El Tribunal Constitucional, I.E.F., Madrid, 1981. 
RoIg Moles, Eduardo: "Una perspectiva regional del debate sobre el futuro de Europa", R.E.P., n. ${ }^{\circ}$ 119, 2003.

RoldÁn BARBERo, J: "La Carta de Derechos Fundamentales de la UE: Su estatuto constitucional", Revista de Derecho Comunitario Europeo, n. ${ }^{\circ}$ 16, año 7, Madrid, 2003.

Roura Gómez, Santiago: "La defensa de la Constitución en la historia constitucional española», C.E.C., Madrid, 1988.

Rousseau, J. J.: Du contrat social au Principes de Droit Politique, París, 1960.

Rubio Llorente, F.: "Una Carta de dudosa utilidad", en Matia Portilla, F. J.: La protección de los derechos fundamentales en la Unión Europea, Civitas, 2002.

Rubio LLORENTE, F.: «Divide et obtempera?. Una reflexión desde España sobre el modelo Europeo de convergencia de jurisdicciones en la protección de los Derechos", REDC, n. ${ }^{\circ} 67,2003$.

RUBIO LlORENTE, F.: «El constitucionalismo de los Estados integrados en Europa", en Rubio y Daranas: Constituciones de los Estados de la Unión Europea, Barcelona, 1997.

Rubio LLORENTE, F.: "El constitucionalismo de los Estados integrados en Europa", en Constituciones de los Estados de la Unión Europea, Ariel, Barcelona, 1997.

Rubio LlORENTE, F..: «La Constitución Española y el Tratado de Maastricht», REDC, n. ${ }^{\circ} 36,1992$.

Rubio Llorente, F.: «La Constitución Española y el Tratado de Maastricht», REDC, n. ${ }^{\circ}$ 36, Madrid, 1992.

Rubio LloRente, F.:: "Mostrar los derechos sin destruir la Unión» REDC, n. ${ }^{\circ}$ 64, Madrid, 2002.

Ruipérez Alamillo, Javier: “¿La Constitución en crisis? El Estado constitucional, democrático y social en los tiempos del neoliberalismo tecnocrático", R.E.P., n. ${ }^{\circ}$ 120, Madrid, 2003.

RuIPÉREZ Alamillo, Javier: La "Constitución Europea» y la teoría del poder constituyente, Biblioteca Nueva, Madrid, 2000.

Ruiz Robledo, Agustín: "Una nota sobre el iter legis en el Tratado de Constitución de la Unión Europea», RFDUC, n. ${ }^{\circ}$ 18, Madrid, 1994.

Ruiz-JARABo ColomeR, D.: "La reforma del Tribunal de Justicia realizada por el Tratado de Niza y su posterior desarrollo», en Moreira Gon- 
zález (coord): Tratado de Niza. Análisis, comentarios y texto, Colex, Madrid, 2002.

SÁlz ARnÁlz, A.: "La carta de los Derechos Fundamentales de la Unión Europea y los ordenamientos nacionales. ¿Qué hay de nuevo?», en Cuadernos de Derecho Público, n. ${ }^{\circ}$ 12, 2001.

SALINAS DE FRÍAS, A.: La protección de los Derechos Fundamentales en la Unión Europea, Granada, 2000.

SÁNCHEZ LEGIDO, A.: "Las relaciones entre el derecho comunitario y el derecho interno en la jurisprudencia del TC», REDC, 1991.

SANTAOLALla GadeA, F.: "La aplicación del Derecho Comunitario en España", en $D A$, n. ${ }^{\circ}$ 201, Madrid, 1984.

SANz CABAllero, S.: "A vueltas con una vieja cuestión: La adhesión de la CE/UE al CEDH tras la Carta de Derechos Fundamentales de la UE», Boletín Europeo de la Universidad de La Rioja, n. ${ }^{\circ}$ 11, 2003.

SCHLEUTER: Das Verfassungsdurchbrechende Gesetz, Gotinga, 1937.

SchmitT, Karl: La defensa de la Constitución, Ed. Tecnos, Madrid, 1983

SchmitT, Karl: Teoría de la Constitución, Madrid, 1992.

SCHNEIDER, H. P.: "La Constitución. Función y estructura», en el Volumen Colectivo Democracia y Constitución, Madrid, 1991.

SCHWARZT, J.: "Verfassungsrecht und Verfassungsgerichtsbarkeit im Zeichen Europas», Nomos Verlagsgesellschaft, Baden-Baden, 1998.

SIEYÈS, E.J.: ¿Qué es el Tercer Estado?, Barcelona, 1985.

Simon, Denys: Le système juridique communautaire, Presses Universitaires de France, París, 1997.

SMEND, Rudolf: Constitución y derecho constitucional, CEC, Madrid, 1985.

Sobrino HeRediA, J. M.: «El sistema jurisdiccional en el Tratado Constitucional», Revista de Derecho Comunitario Europeo, n. ${ }^{\circ}$ 16, 2003.

SolanA, J.: "Desafíos de la defensa europea», Política Exterior, n. ${ }^{\circ}$ 79, Madrid, 2001.

SolozÁBAL EChAVARRÍA, Juan José: "Constitución y orden constitucional en la Unión Europea», R.E.P., n. ${ }^{\circ}$ 119, Madrid, 2003.

STEIN, Torsten: "La Constitución europea: Pasado, presente y futuro", Anuario Jurídico de La Rioja. Anales del Convenio Universidad de La Rioja-Diputación General de la Rioja 2.1996. 
STEIN, Torsten: "La sentencia del Tribunal Constitucional alemán sobre el Tratado de Maastricht", en Revista de Instituciones Europeas, n. ${ }^{\circ}$ 3, 1994.

Stern, Klaus: Derecho del Estado de la República Federal Alemana, C.E.C., Madrid, 1987.

TAJAdura TEJAdA, Javier: El preámbulo constitucional, Ed. Comares, Granada, 1997.

TAJAduRA TEJADA, Javier: “¿El ocaso de Westfalia? Reflexiones en torno a la crisis del constitucionalismo en el contexto de la mundialización", R.E.P., n. ${ }^{\circ}$ 123, Madrid, 2004.

TAJAduRA TEJADA, Javier: "La crisis de la Constitución en el proceso de integración europea", Revista de Derecho Político, n. ${ }^{\circ}$ 53, Madrid, 2002.

TorreblanCA, J. L.: ¿Quién teme a la Convención?, Real Instituto Elcano de Estudios Internacionales y Estratégicos, www.realinstitutoelcano.org.

Truyol y SerRA, A.: La integración europea, Madrid, 1999.

URREA CoRRES, M.: La cooperación reforzada en la Unión Europea: Concepto, naturaleza y régimen jurídico, Colex, Madrid, 2002.

URREA CorRes, Mariola: «El dilema de la Convención: la búsqueda de una solución alternativa al modelo clásico de reforma de los Tratados", Revista de Derecho Comunitario Europeo, n. ${ }^{\circ} 14$, enero-abril 2003.

VIDAL BenEYTo y otros: El reto constitucional de Europa, Dykinson, Madrid, 2004.

VIDAl Quadras-Roca, Alejo y otros: La cividad europea, Dykinson, Madrid, 2005.

VIRgala ForuRIA, Eduardo: «EI Poder Ejecutivo en la UE: Consejo y Comisión", R.E.P., n. ${ }^{\circ}$ 119, Madrid, 2003.

VITORINO, A.: "La Charte des droits fondamentaux de I'Unión européenne», Revue du Droit de I'Union Europeene 3/2000.

Von Bogdandy, A, BAst, J., ARndt, F:»Tipología de los actos en el derecho de la Unión Europea. Análisis empírico y estructuras dogmáticas en una presunta jungla», Revista de Estudios Políticos, n. ${ }^{\circ}$ 123, Madrid, 2004.

Von Bogdandy, A. (ed.): Europäisches Verfassungsrecht, Springer, Berlin, 2003. 
Von Gerber, C. F.: Diritto Publico, Milán, 1981.

VV.AA.: "La Constitución Europea» bajo la dirección de M. OREJA AgUIRRE. Actas de El Escorial, Universidad Complutense, Madrid, 1994.

Weber, A.: "Consideraciones en torno a la Carta de los Derechos Fundamentales de la Unión Europea», en R.E.D.C., n. ${ }^{\circ}$ 64, 2002.

Weber, A.: "La Carta de los Derechos Fundamentales de la Unión Europea", $R E D C$, n. ${ }^{\circ} 64,2002$

WEBER, Albrecht: «El control del Tratado de Maastricht por la jurisprudencia constitucional desde una perspectiva comparada", en REDC, n. ${ }^{\circ} 45,1995$.

WEILER, J.: "Federalismo y constitucionalismo. El Sonderweg de Europa", Revista de Occidente, 2002.

WEILER, J.: "La transformación de Europa», en Europa, fin de siglo, CEC, Madrid, 1995.

WEILER, J.: The Constitution of Europe: Do the new clothes have an emperor? And other essays, Cambridge University Press, 1999.

WHEARE, K. C.: "Modern Constitutions", en Home University Library of Modern Knowledge. Londres, 1951.

WISE, John: "A vindication for the Government of the New England Churches. A Drawn from Antiquity; The Light of Nature; Holy Scripture; Its Noble Nature; and from the Dignity divine Providente has put upon it», Boston, 1772. 1. ${ }^{\text {a }}$ edición 1717.

ZipPelIUs, R.: Teoría general del Estado (Ciencia de la Política), México, 1985.

\section{ADDENDA}

Dice así el artículo IV-447. Ratificación y entrada en vigor.

1. «El presente Tratado será ratificado por las Altas Partes Contratantes, de conformidad con sus respectivas normas constitucionales. Los instrumentos de ratificación serán depositados ante el Gobierno de la República Italiana.

2. El presente Tratado entrará en vigor el día 1 de noviembre de 2006, siempre que se hayan depositado todos los instrumentos de ratificación o, en su defecto, el primer día del segundo mes siguiente al 
del depósito del instrumento de ratificación del último Estado signatario que cumpla dicha formalidad.

La fecha prevista en la norma transcrita para la entrada en vigor del "Tratado por el que se establece una Constitución para Europa», firmado en Roma el día 29 de octubre de 2004, no se va a poder cumplir; el motivo lo encontramos en que el manido "déficit democrático" ha terminado pasando factura en el caso de dos Estados miembros fundadores de la Europa Unida. Los días 30 de mayo y 1 de junio de 2005, franceses y holandeses, respectivamente, se pronunciaron de forma negativa, en consulta popular, sobre la llamada Constitución Europea. Estos referendos, convocados de acuerdo con lo establecido en sus ordenamientos internos, le permitieron al pueblo de los citados Estados fundadores expresar su opinión por vez primera a lo largo de estos casi cincuenta años de vida que tiene la actual Europa de los mercados.

Como "el pueblo siempre tiene razón» estas negativas rotundas han sumido en el estupor y en la confusión a los líderes de los Estados soberanos acostumbrados a avanzar en la construcción europea a espaldas de la ciudadanía. Pero, si no era suficiente la crisis política para evidenciar el mal momento por el que atraviesa la ampliación, en el mismo mes de junio, los días 16 y 17, la Cumbre de Bruselas añadió una crisis financiera al concluir sin haber alcanzado un acuerdo sobre el Marco Financiero Plurianual para el período 2007-2013. El desacuerdo se centró principalmente en los temas relacionados con el llamado "cheque británico" o dinero que la Unión Europea devuelve anualmente a Inglaterra, desde 1984, época en la que M. Tatcher era Primera Ministra del Reino Unido (es evidente que ha quedado obsoleto en el momento presente); y también en la necesaria reforma de la P.A.C. (Política Agraria Común), que afecta principalmente a Francia y al resto de los países mediterráneos, entre los que España es un beneficiario neto.

En una situación de "Crisis de reflexión activa" (MORATINOS), para intentar superar el momento en que los ciudadanos se han revelado y los Estados no se ponen de acuerdo en el modelo de la Europa que se quiere y necesita no ha quedado otro remedio que "congelar el texto de la inédita Constitución Europea y abrir una fase de reflexión al respecto" (B. FERRERO-WALDNER). Se ha intentado frenar el efecto dominó de las consultas negativas en Francia y en Holanda, y pese al referéndum afirmativo de Luxemburgo de fecha 10 de julio de 2005 el oxígeno no llega en cantidad suficiente a esta Europa que ha dado un paso atrás y aún no encuentra el camino para dar dos pasos adelante en su ambiciosa fase de ampliación masiva. 
En el momento de redactar estas líneas (julio de 2005), son ya mayoría los países -en total trece-y el volumen de la población —más del cincuenta y uno por ciento-, que se han pronunciado de forma afirmativa a la hora de ratificar el Tratado por el que se establece una Constitución para Europa: mediante referéndum lo han hecho España y Luxemburgo, y por vía parlamentaria, Austria, Chipre, Alemania, Grecia, Hungría, Italia, Letonia, Lituania, Malta, Eslovenia y Eslovaquia. En breve lo harán por vía parlamentaria Estonia y Bélgica, y el resultado se espera positivo. En cambio, han postergado el proceso "sine die" ocho países: Reino Unido, República Checa, Dinamarca, Irlanda, Polonia, Portugal, Suecia, y Finlandia.

El resultado positivo de la consulta luxemburguesa no ha solventado los problemas de la Europa de la ampliación, pero deja un margen a la esperanza después del fracaso de la cumbre de Bruselas del pasado mes de junio, en la que, los líderes solo alcanzaron un acuerdo para prolongar, por lo menos durante un año, el plazo de la entrada en vigor del Tratado Constitucional. Y, es que hasta el 2007 los países que se han pronunciado negativamente no van a estar en condiciones - después de celebrar nuevas elecciones generales-, de renegociar el texto. Hasta ese momento disponemos de un plazo de tiempo para la reflexión en el que todo consenso y colaboración van a resultar escasos. Se ha puesto de manifiesto de forma evidente la ausencia de un plan alternativo para sustituir al fracasado intento de establecer un Tratado Constitucional. Y seguimos estando en el ámbito de un Tratado de Niza de 2001, vigente pero insuficiente para el funcionamiento de la actual Europa de los Veinticinco que pretende convertirse en una potencia mundial en la era de la globalización y de la revolución tecnológica.

Este semestre corresponde la Presidencia de turno de la Europa Unida al premier británico T. Blair, que afronta la dirección de esta organización supranacional después de haber obtenido una victoria pírrica en la última cumbre, frente al primer ministro luxemburgués y el resto de los líderes europeos. El ambiente está enrarecido en una Europa paralizada en la que no se tiene una idea clara del modelo a seguir y por ello los proyectos político y financiero siguen sin resolverse. Los daños colaterales no se han hecho esperar y los primeros en sufrirlos han sido los países candidatos a la adhesión. En Europa, como previamente se hizo en Norteamérica, (COLOMER), debe ser requisito indispensable profundizar en el modelo institucional para luego ampliar en consecuencia y con ello perseguir el éxito de cerca. Pero, se empezó la casa por el tejado y los países aspirantes han visto frenados sus deseos. El Tratado Constitucional se ha congelado y se han ralentizado las nuevas ampliaciones referidas a los países balcánicos, Ucrania, ... y 
también existe gran incertidumbre a cerca de la suerte que le espera en este ámbito a Turquía. Únicamente parece asegurada la adhesión de Rumanía y Bulgaria, ya firmadas, pero, la fecha prevista para el año 2007 puede sufrir modificaciones. Los diez nuevos miembros de pleno derecho desde el día 1 de mayo de 2004 han sufrido el boicot del pacto financiero por parte del primer ministro inglés, que les hubiera reportado unos recursos de ciento treinta mil millones de euros. $Y$ eso, a pesar de haberle apoyado en la crisis europea por la guerra de Irak.

La política agraria común también debe ser revisada como lo será igualmente el llamado "cheque británico" del que se beneficia el Reino Unido por participar en menor medida en la P.A.C. Pero sobre todo el gran perdedor en el fracaso de la Cumbre de Burselas de junio de 2005 ha sido el eje franco-alemán. Han fracasado los líderes políticos de estos países, verdaderos motores del proyecto internacional en crisis, así como también lo han hecho los modelos por ellos propuestos. Debido al ataque sufrido por la alianza de los líderes políticos de Inglaterra, Suecia y Holanda. Las perspectivas de futuro no son halagüeñas porque quienes se perfilan como vencedores en las próximas contiendas políticas nacionales en Francia y Alemania están más próximos al modelo socioeconómico defendido por el señor Blair.

Como la cumbre de junio no se intuía exitosa, el Presidente de la Comisión, señor Durao Barroso encargó a los correspondientes servicios jurídicos un estudio en el que se concluye que, a corto plazo, únicamente podrían aplicarse tres puntos de la llamada Constitución Europea. Este análisis jurídico se encomendó en el convencimiento de que, al parecer, se tiene la seguridad de que el nuevo Tratado no podrá aplicarse ya en la situación de redacción actual y la Unión Europea no tendrá una alternativa al mismo hasta que no hayan transcurrido, como mínimo, dos o tres años. Entre tanto, en opinión fundada de los Servicios Jurídicos del ejecutivo comunitario —que defiende los intereses de la Unión-, solo podrán aplicarse tres aspectos del Tratado Constitucional sin que para ello sea necesario modificar el vigente Tratado de Niza o de someterlas a la ratificación de los veinticinco Estados miembros. Estas materias serían:

1. ${ }^{a}$ La iniciativa popular, según la cual «un grupo de al menos un millón de ciudadanos de la Unión que sean nacionales de un número significativo de Estados miembros, podrá tomar la iniciativa de invitar a la Comisión en el marco de sus atribuciones a que presente una propuesta adecuada" sobre una iniciativa legal concreta. (Artículo l-47,4 del T.C.E.).

2. ${ }^{a}$ También puede salvarse la vía abierta para que un proyecto legislativo de la Unión Europea quede frenado si un tercio de los parla- 
mentos nacionales lo objeta (artículo l-11,3 y el protocolo sobre el principio de subsidiariedad)..

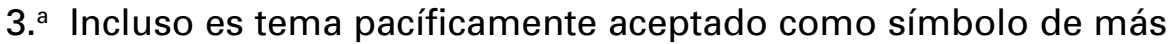
democracia y transparencia en el funcionamiento de las instituciones de la Unión la obligación para el Consejo de Ministros de "reunirse en público cuando delibere y vote sobre un proyecto o acto legislativo" (artículo I-24,6 del T.C.E.).

Todas estas previsiones, se destaca en el informe, inciden en el interés de que la vida democrática de la Unión se incentive, porque la consecución de este objetivo es algo reclamado de forma reiterada por la ciudadanía de todos los Estados miembros durante las campañas para ratificar el nuevo Tratado.

En medio de la falta de certeza sobre lo que sucederá con los contenidos del Tratado Constitucional (ratificado de momento en trece países, rechazado en dos, suspendido en ocho, y pendiente de ratificación por vía parlamentaria en otros dos Estados), los problemas que con carácter general debe resolver la Europa unida en la diversidad para salir de esta situación de "impasse" y poder avanzar hacia el futuro serían principalmente los siguientes:

1. ${ }^{\circ}$ consensuar un modelo europeo en el que, en primer lugar, se obtenga una idea de la Europa que se quiere y se proceda, a continuación, a la ampliación del número de miembros que compongan esta organización supranacional. Es preciso meditar sobre la posible existencia de límites a la ampliación. Porque lo que Europa no puede permitirse es morir de éxito. $Y$ hemos de ser conscientes de que lo que en realidad está sometido a juicio en la disputa constitucional europea es el futuro del capitalismo no solo en Europa sino en el resto del mundo. (J. RIFKIN).

2. Proceder con cautela a la reforma en el campo económico para introducir un modelo que afronte los problemas del paro y del crecimiento de la economía que no parece repuntar por el momento. Hemos de convencernos de que los dos modelos en presencia tienen ventajas e inconvenientes, pero, las conquistas conseguidas en el terreno social y de los derechos de prestación no deben perderse, ya que, si triunfa el modelo neoconservador del paradigma propuesto por el premier británico, habrá más mercado y menos Estado (J. HABERMAS). Podrá despegar la economía pero siempre a costa de los derechos de los más débiles, es decir, de la clase trabajadora; la modernización del modelo social europeo no puede quedarse únicamente en las medidas socioliberales propuestas por Blair y que, de momento, parecen conseguir 
cada día más adeptos. (T. GARTON). Los derechos sociales contenidos en la Carta de los Derechos Fundamentales y en el Tratado Constitucional, en su parte II, deben ser consideraros la clave de bóveda de la Unión Europea, como también deben serlo el desarrollo de un marco europeo de negociación colectiva., el establecimiento de políticas expansivas, la armonización de las políticas fiscales, el estímulo del crecimiento económico, como objetivo del Banco Central Europeo ...(V. NAVARRo). Todas estas medidas ponen de manifiesto que "para salvar a Europa" se requiere "más Europa», es decir, una mayor expansión y profundización de su dimensión política y social.

3. ${ }^{\circ}$ Otra cuestión no resuelta es la necesidad de tomar las medidas imprescindibles para garantizar la tolerancia e integración étnica, sobre todo en relación con la inmigración musulmana; se trata de trabajadores necesarios para la renovación de la fuerza laboral entre una población europea que envejece y que precisa de la existencia de mano de obra joven que, además, contribuya a sostener nuestro sistema de seguridad social. Esto se puede conseguir con regulaciones normativas integradoras no excluyentes, en las cuales los flujos migratorios se contemplen de forma uniforme en todos los países contribuyendo con ello a lograr una mayor seguridad en la zona. (B. SCHEFfER). Aumenta la libertad individual con la desaparición de las fronteras y sin duda esto origina el incremento de la inseguridad y de la sensación de impotencia. El mercado común europeo debe implicar la posibilidad de ejercer de contrapeso ante la nueva competencia de economías emergentes, y gracias a ello la defensa del modelo social que nos hemos dado. Ante el riesgo de su desaparición la ciudadanía se ha pronunciado y es preciso tomar nota. (I. SOTELO).

4. Debemos insistir también en la superación del llamado «déficit democrático". Esto se puede lograr poniendo caras a las instituciones, democratizándolas en la mayor medida posible y haciendo que figuras como el Presidente del Consejo Europeo se elijan por sufragio popular. Como esto no es suficiente será preciso también configurar una Europa política y no solo económica que actúe en el ámbito político hacia dentro y hacia fuera, y para ello no bastan simples acuerdos intergubernamentales.

Una Constitución debe ofrecer el marco institucional en el que discutir sobre alternativas políticas. Las Constituciones supranacionales no nacen de una acto revolucionario fundacional, como los modelos clásicos (Gomes CANOTILHO). Se crean a lo largo de muchos años y su fundamento se encuentra en Estados que garantizan, previamente, las libertades fundamentales; por esto, el proceso lo impulsan los gobiernos 
y no los ciudadanos que hasta el momento presente, en periodo de abundancia, se encontraban satisfechos con el modelo establecido. En momentos de escasez e incertidumbre mundial, los ciudadanos quieren disponer de un proyecto de futuro que sin duda influirá en sus vidas. La Europa unificada en la diversidad para obtener el apoyo de la ciudadanía tiene que ir acompañada de una perspectiva política y no solo económica (J. HABERMAS).

En conclusión: los grandes cambios históricos nunca se han producido sin señales que se convierten en referente para las generaciones futuras. El fracaso del Tratado Constitucional, de momento, podemos considerarlo un acto simbólico a este respecto. 